\title{
MULLĀ ȘADRĀ'S POLITICAL LEGACY: ȘADRĀ'S THEORY OF JUSTICE AND THE RELIGIO-POLITICAL AUTHORITY IN POST-REVOLUTIONARY IRAN
}

\author{
Amir Rastin Toroghi \\ Ferdowsi University of Mashbad, Mashbad-Iran \\ arastin@ferdowsi.um.ac.ir \\ https://orcid.org/0000-0002-2823-8649 \\ \& \\ Seyyed Mortaza Hosseini Shahrudi \\ (Corresponding author) \\ Ferdowsi University of Mashbad, Mashbad-Iran \\ shahrudi@ferdowsi.um.ac.ir \\ https://orcid.org/0000-0003-2451-9088
}

\begin{abstract}
Apart from its philosophical attractions, the religio-political potentials in the transcendent philosophy of Mullā Ṣadrā Shīrāzì (d. 1050/1641) have helped to its dominance in the seminary and university in contemporary Iran. It seems that one of the reasons for the state's support for al-Hikmah al-muta'äliyah in Iran after the Islamic revolution is the potentials existing in this philosophy to justify the establishment of a religious government based on the discourse of Shí $\bar{i}^{\overline{1}}$ political authority, conspicuously the doctrine of walayat-i faqīh (the guardianship and governance of the jurist). This article aims to demonstrate how Mullā Șadrā's theory of moral and social justice could
\end{abstract}

Volume 11 Number 2 Summer / Fall 2020

DOI: $10.12730 / 13091719.2020 .112 .210$

Copyright $($ C Bursa İlahiyat Foundation

Received: June 12, 2020 Accepted: November 25, 2020

Published: December 31, 2020

To cite this article: Rastin Toroghi, Amir, and Seyyed Mortaza Hosseini Shahrudi. "Mullā Șadrā's Political Legacy: Șadrā's Theory of Justice and the Religio-Political Authority in Post-Revolutionary Iran." Ilabiyat Studies 11, no. 2 (2020): 253-294. https://doi.org/10.12730/13091719.2020.112.210 
have provided an intellectual ground for the establishment of an Islamic state in the Shī̄i sense.

Key Words: Mullā Ṣadrā, justice, moral justice, social justice, authority of the jurist (walāyat-i faqīh)

\section{Introduction}

In many of his writings, Șadr al-muta'allihīn has dealt with transcendent politics (a political system believed to be taken from Transcendental Philosophy or al-Hikmah al-muta'äliyah which is the school of philosophy founded by Mullā Șadrā), while most of his political discussions can be found in al-Shawābid al-rubübiyyah and $a l-M a b d a^{\prime} w a-l-m a^{\prime} \bar{a} d$. One should not expect him to rise up and explicitly talk or engage in political issues at an age when he was actually exiled to a small village near Qom - Kahak - due to the expression of some of his beliefs, including the unity of being. How can a scholar who is not allowed to freely express his scientific views think of undertaking the country affairs? He must be smart enough to wait for the right opportunity or pave the way for others to benefit from his thought in the future. ${ }^{1}$ Having this in mind, we argue that Șadrā's method of approaching sociopolitical issues is similar to his method in discussing his special philosophical issues. He does not offer his special ideas in plain wording, but scatter them in different positions with an implicit language; it is up to his followers in later periods to infer and explicate them. In the introduction of al-Shawäbid alrubübiyyah, he says,

I have deposited some of these issues in dispersed parts of books and treatises. I could not explicitly express many of them because I afraid of becoming famous and prevented them from being spread in all regions, due to the incapacity of the unpurified natures to understand them... And this [misunderstanding] may cause to go astray and to lead others astray. ${ }^{2}$

See Javādī Āmulī, "Ḥikmat-i Șadrāc̄ì wa-sīyāsat-i mutacāliyah dar neshastī ba Ayatollah Javādī Āmulī," Pigāh-i Hawzah 247, no. 19 (1387 HS).

2 Mullā Ṣadrā Muḥammad ibn Ibrāhīm ibn Yaḥyá al-Shīrāzī, al-Shawāhid alrubūbìyah fì l-manāhij al-sulūkiyyah, ed. Jalāl al-Dīn Āshtiyānī, $5^{\text {th }}$ ed. (Qom: Bustān-i Kitāb, 1388 HS) 132; see also Mullā Șadrā, İqāz al-nā’imìn, ed. Muhsin Mu’ayyid (Tehran: Islamic Institute for Research in Philosophy, n.d.), 4; id., "Risālat 
A few studies in almost the last three decades have come to discuss the political legacy of Mullā Șadrā in modern Iran, especially his influence on one of his commentators in our contemporary time, Ayatollah Khomeini. ${ }^{3}$ Rizvi asserts that Imām Khomeini has encouraged the linkage of the study of philosophy and mysticism with the political theory of juristic authority or walayyat-i faqīh and 'Allāmah Țabātabā'̄i and some of their prominent students have written major works defending the juristic theory in the language of philosophy and mysticism. ${ }^{4}$

In his only official written letter to a foreign leader, on 1 January 1989, Imām Khomeini invited Mikhail Gorbachev, the General Secretary of the Soviet Union, to let their scholars become familiar with transcendental philosophy of Mullā Ṣadrā. ${ }^{5}$ Ayatollah 'Abd Allāh Javādī $\bar{A}$ mulī, one of Khomeini's major students and one of the contemporary leading tutors of philosophy and exegesis in Iran and above all, the head of the Iranian delegation to deliver this historical letter, argues that "many of the issues in this letter are related to al-Hikmah almuta'áliyah and the Iranian deputy did not only deliver it but also taught its content in an hour."

Some recent studies have also tried to bring Mullā Șadrā's political legacy to light. Sayeh Meisami's Knowledge and Power in the Philosophies of Hamìd al-Dīn Kirmānì and Mullā Sadrā Shìrāzì is a good example. Discussing the connection between the concept of knowledge and power in Ṣadrā, she has tried to argue that Șadrā's synthetic discourse, either intentionally or unintentionally, has contributed to the formation of the modern theory of religio-political

shawāhid al-rubūbiyyah," in Majmū' $i$ rasā'il-i falsafí-yi Șadr al-muta'allibìn, ed. Ḥāmid Nājī Ișfahānī (Tehran: Intishārāt-i Ḥikmah, 1375 HS), 284.

3 Rizvi has cited some of these studies: Sajjad Rizvi, "Only the Imam Knows Best: The Maktab-i Tafkīk's Attack on the Legitimacy of Philosophy in Iran," The Journal of Royal Asiatic Society 22, no. 3-4 (2012), 490, https://doi.org/10.1017 /S1356186312000417.

4 Ibid.

5 Rūḥullāh Khomeini, "Ṣahịfa-yi Imām," in An Anthology of Imām Khomeini's Speeches, Messages, Interviews, Decrees, Religious Permissions, and Letters. vol. 21, trans. Manșūr Limba, ed. Husayn Karamyār and Ja‘far Rāzī Khān (Tehran: Institute for Compilation and Publication of Imām Khomeini's Works, 2008), 224-225.

6 Javādī Āmulī, "Siyāsat-i muta‘āliyah az manẓar-i ḥikmat-i mutacāliyah," Hikmat-i Isrā 7 , no. 3 (1390 HS), 16. 
authority of the jurist or walayyat-i faqīh in Iran. ${ }^{7}$ Șadrā's influence can also be discussed from a more political perspective and that is from the angle of his theory of justice. We try to scrutinize his works to infer and explain his narrative of justice with regard to his philosophy, theology, and commentary on the holy Qur’ān and Shī̄i traditions. At many points amid the discussion, as well as in a separate final section (The Realization of Justice) in particular, we deal with the relationship between Șadrā's theory of justice and the philosophical ground it prepares for the establishment of religious authority. We argue that there are undeniable potentials in Șadrā's discourse which anticipate the formation of walayat-i faqīh. Also, there are other aspects of Șadrā's philosophy which may be connected with the theory of walāyat-i faqīh especially in Ayatollah Khomeini's case; for instance, Nasr and Javādī Âmolī have related Khomeini's engagement in political affairs after living an ascetic and gnostic life to the fourth stage of the human's journey to God (al-asfär al-arba'ab) upon which the whole structure of al-Hikmah al-muta'āliyah of Mullā Șadrā is based; the fourth stage includes the "return from God to creation with God" (alsayr fi l-khalq bi-l-Haqq) as a mission to help others take on the journey toward Him. ${ }^{8}$

As for the influence of al-Hikmah al-muta'äliyah on the Islamic revolution, it has been narrated from Ayatollah Khomeini to have said that "The revolution has been formed by two books: al-Asfär al-

Sayeh Meisami, Knowledge and Power in the Philosophies of Hamid al-Din Kirmānì and Mullā Șadrā Shīrāzì (New York: Palgrave Macmillan, 2018), 161, https://doi.org/10.1007/978-3-319-71192-8.

8 See Seyyed Hossein Nasr, "Theoretical Gnosis and Doctrinal Sufism and Their Significance Today," Transcendent Philosophy 1 (2005), 19; Javādī Āmulī, Walāyat-i faqīh: Walāyat-i feqāhah wa-'adālah, ed. Muḥammad Mehrabī (Qom: Esra International Foundation for Revealed Sciences, 1389 HS), 262-266. Khomeini believes that it is at the fourth state of the journey that the wayfarer "codifies laws, makes the rulings: the outward, formal and the inward, supraformal, reports and communicates on behalf of God, His attributes, His names and His true teachings in proportion to the preparedness of creatures." Khomeini, The Lamp of Guidance into Vicegerency and Sanctity, trans. Salam Judy (Tehran: Institute for Compilation and Publication of Imām Khomeini's Works, 2010), 117. Jalāl al-Dīn Āshtiyānī also asserts that the wayfarer at this stage is qualified for establishing the Ideal City and dealing with all the affairs of the human society; see Āshtiyānī, Sharh Muqaddameyi Qayṣarī bar Fuṣuṣ al-ḥikam (Tehran: Amirkabir Publication, 1370 HS), 667-668. 
arba'ah by Șadr al-muta'allihīn and Jawhar al-kalām, by al-Najafî." Apart from Imām Khomeini, many other significant founders of the revolution were also influenced by Șadrā's philosophy. After Khomeini, we have to mention Ayatollah Morteza Motahhari, who was somehow a reviver of transcendent philosophy by answering the newly emerging philosophical and ideological issues. Being a prominent master in Islamic philosophy and using its principles, especially al-Hikmah al-muta'äliyah, he confronted those schools of thought that were against that of the founders of the Islamic Revolution in the pre-revolutionary period, especially the schools of capitalism, socialism and Marxism. Therefore, alongside his numerous writings (among them highly specialized works in al-Hikmah al-muta'āliyah like Dars-hā-yi Asfār and Sharḩ-i Mabsūț-i Manzūmah stand out), Motahhari had many religious, philosophical, and revolutionary lectures and especially had a serious presence in planning, promoting, and managing the affairs of Hosseinieh Ershad which was finally closed by the Pahlavi regime in 1972. He, like Șadrā, considers justice as one of the important goals of establishing a government. Motahari is in the same story with Mullā Ṣadrā in defining justice and its being based on the existential world. In his view, the true meaning of social justice is to respect the rights of individuals. According to him, the basis of justice is based on rights, and these rights exist inherently in the world of creation and also in the human world. ${ }^{10}$

Ayatollah Mohammad Hossein Beheshti ${ }^{11}$ was another student of 'Allāmah TTabāṭabā'̄i and Imām Khomeini, who played a very important role in the formation and victory of the Islamic Revolution, and in the post-revolutionary period, he had important responsibilities such as the first head of the judicial system and the most influential person to design the constitution and to defend its philosophical and political principles. Studying philosophy both in seminary and university, Beheshti had been directly influenced by Islamic philosophy, especially Transcendent Wisdom. He was one of the attendees at the sessions where 'Allāmah Ṭabāțabā'î's famous articles,

9 "Gozāresh-i neshastha-yi Wujūh-e Sīyāsī-yi Hikmat-i Mutacālīyah," Pigāh-i Hawzah 217, no. 27 (1386 HS), https://hawzah.net/fa/Magazine/View/3814/4876 /40581, accessed November 15, 2020.

10 Motahhari, Collection of Works (in Persian) (Tehran: Sadra, 1373 HS), I, 80-81.

11 For a detailed narrative of his life and activities, see Rāst-qāmatān-i Jāwdāne-yi Tārīkh-i Islām (Tehran: Bonyād Shahīd, 1361 HS). 
later published under the title of Ușūl-i Falsafah wa-Rawesh-i Reālism, were discussed. In his view, in line with the theories of philosophers such as Mullā Șadrā, the government is formed to protect the right and justice. This government is established based on the best of schools, i.e. the school of Islam, and follows the model of "ummah and imāmate" in which among from the general public those who gather on the axis of the school of Islam from among the general public have special precedence and priority. The ummah, according to the Islamic ideology, definitely needs Imāmate (leadership in its broad sense which also includes highly qualified scholars) and makes the leader be at the top level of priority to lead the nation. ${ }^{12}$ Naturally, such priorities can be compatible with justice-as the goal of establishing governmentonly if they are rooted in the creation-one of the important facts in Șadrā's theory of justice.

Regardless of the fact that many leaders and thinkers involved in the victory of the Islamic Revolution were among the philosophers of Transcendent Wisdom, the impact of hikmat-i muta' $\bar{a} l \bar{i} y a h$ after the revolution in terms of supporting the intellectual foundations and philosophical principles of the Islamic Republic is also significant. Suffice it to just name some of the Transcendent philosophers who have been supporting the Islamic Republic of Iran and especially the theory of walāyat-i faqī in the post-revolutionary Iran; scholars and philosophers such as Ayatollah Javādī Āmulī, Ayatollah Mesbah Yazdī, Ayatollah Hassan Zadeh Āmolī, Hujjat al-Islām Ahmad Ahmadī, Khosropanah, Rashad, Gholamreza Fayazī, Parsania, Yazdanpanah, Rahimpour Azghadī, and many others. Further studies may help to shed light on these aspects of influence Șadrā's philosophy has had on post-revolutionary Iran.

\section{Definition of Justice}

Muslim scholars have proposed two general definitions for justice; but if they are analyzed accurately, they would be deemed as one. The first definition is "to put everything in its proper position" 13 and the

12 Tālebi Darabī, "Insān wa-Jahān dar Niz̄ām-i Fikrī-yi Shahīd Beheshtī," Pigāh-i Hawzah 217, no. 185 (1385 HS).

13 Samīh Dughaym, Mawsū'at muștalaḥāt al-Imām Fakhr al-Dīn al-Rāzī (Beirut: Maktabat Lubnān Nāshirūn, 2001), 441. 
other, "to preserve the rights of the rightful."14 Nasr considers these meanings for justice to be somehow self-evident when he speaks of justice as "the intuitive sense of putting things aright and in their appropriate place, ... [and] of giving each being its due." ${ }^{15}$ Rūmī (d. 1273) - the great Persian poet and mystic whose poetry has been repeatedly cited by Mullā Șadrā (d. 1640) ${ }^{16}$ - has versified the two definitions as follows,

What is justice? To put (a thing) in its right place

What is injustice? To put (a thing) in the wrong place. ${ }^{17}$

What is justice? Giving water to trees.

What is injustice? To give water to thorns. ${ }^{18}$

It seems that these are not two independent separable definitions; when something or someone is put aright, that has been given its due and right. Mullā Șadrā admits both uses; he considers God as "Just" because He has put every being in its appropriate place ${ }^{19}$ and, alluding to the verse of trust, ${ }^{20}$ he attributes injustice to humans since he puts

14 Husayn Tavassulī, Mabānī-yi Nazarầ-yi 'Adālat-i Ijtimā' ${ }^{\prime} \bar{\imath}$ (Tehran: Bunyād-i Mustaḍ’afān-i Inqilāb-i Islāmī, 1375 HS), I, 159-175.

15 Nasr, "Introduction," in The Sacred Foundations of Justice in Islam: The Teachings of 'Ali ibn Abi Ṭālib, ed. M. Ali Lakhani (Bloomington, Ind.: World Wisdom \& North Vancouver, B.C., Canada: Sacred Web Pub., 2006), xi.

16 For instance, see, Mullā Șadrā, al-Hikmah al-muta'āliyah fì l-asfār al-'aqliyyah al-arba'ah (al-Asfār) (Beirut: Dār Iḥyā' al-Turāth, 1981), II, 334. Id., "Iksīr al'ārifīn,” in Majmū'at al-rasā'il al-tis'ah (Tehran: n.p., 1302 A.H.), 313; id., Risālayi Se Aṣl, ed. Seyyed Hossein Nasr (Tehran: Tehran University, 1340 HS), I, 71-72; id., "Ajwibat al-masā’il al-Kāshāniyyah," in Majmū'i Rasā’il-i Falsafì-yi Ṣadr alMuta'allihīn, ed. Hāmid Nājī Iṣfahānī (Tehran: Intishārāt-i Ḥikmah, 1375 HS), 149150; Mullā Ṣadrā, İqāz al-nā'imīn, 11, 62, 65, 71; Mullā Ṣadrā, Kasr aṣnām aljāhiliyyah, ed. Jahangiri (Tehran: Sadra Islamic Philosophy Research Institute, 1381 HS), 179; id., Tafsīr al-Qur’ān al-Karìm, ed. Muḥammad Khwājawī (Qom: Intishārāt-i Bīdār, 1366 HS), V, 245.

17 Mawlānā Jalāl al-Dīn-i Rūmī, Mathnawī-yi Ma'nawì, ed. Tawfīq Subḥānī (Tehran: Organization of Publishing of Ministry of Culture, 1373 HS), 914.

18 Ibid., 684 .

19 Mullā Ṣadrā, Sharḥ Ușūl al-Kāfì, ed. Muhammad Khwājawī (Tehran: Mu’assasa-yi Muțāla‘āt wa-Taḥīịāt-i Farhangī, 1383 HS), III, 285-286.

20 "Indeed, We presented the Trust to the heavens and the earth and the mountains, but they refused to undertake it and were apprehensive of it; but man undertook 
the divine trust out of its appropriate place. ${ }^{21}$ As for the other use of justice, the divine providence and mercy is deemed as just since it has paid every being its due (al-haqq) and has bestowed upon every talent what it is worthy of $;{ }^{22}$ on the opposite, people do not let the true justice be observed in this corporeal world by depriving each other of many of their rights,

This world is not the world of residence and stability, neither the place of goodness, completeness, and perfection, nor the source of justice, light, and happiness. For we see that the rights do not reach to those who deserve, but to those who do not deserve. ${ }^{23}$

Basically, in Șadrā's view, paying dues and rights is equal to the observance of justice, something which is intrinsic and innate in every human being. ${ }^{24}$ Therefore, justice is a single truth and has got one single meaning with two aspects. Șadrā uses terms 'adl, 'adālah, $i$ 'tidāl to refer to justice, and as we will see, he applies justice to a wide scope encompassing three major realms of creation, buman soul, and community.

\section{The Rationale behind Being Just}

Existence or "wujū d" is the central issue of Mullā Șadrā's philosophy as far as it is recognized as an "existential philosophy." The most important principle in his Transcendent Philosophy or al-Hikmah almuta'aliyah is the ontological originality and primacy of existence (așālat al-wujūd). Așālat al-wujūd is a doctrine rooted in the Avicenna's (d. 1037) distinction between existence and essence in contingent beings. After Avicenna, a controversy emerged in the Islamic East, as to which of the existence or essence is the reality of the things and which is the mere mental abstraction of the reality. Most philosophers especially Ishrāqiyyūn, led by al-Suhrawardī (d. 1191), thought essence to be the reality and existence a mere subjective

it. Indeed, he is most unjust and ignorant." (Q 33: 72). All the English translations of Qur'ānic verses throughout this paper is from The Holy Qur'ān, Qara'i, trans.

21 Mullā Ṣadrā, "Ajwibat al-masā’il al-Kāshāniyyah," 148.

22 Mullā Șadrā, "Risālah fī l-wāridāt al-qalbiyyah," in Majmū'at al-rasā’il al-tis‘ah, 251.

23 Mullā Șadrā, Mafātīḥ al-ghayb, ed. Muhammad Khwājawī (Tehran: Mu’assasa-yi Taḥqīāt-i Farhangī, 1363 HS), 441.

24 Mullā Ṣadrā, Sharḅ Ușūl al-Kāfì, IV, 140. 
abstraction. ${ }^{25}$ On the other side, Muta'allibìn, led by Mullā Șadrā, advocated the originality of the existence, a doctrine that renders the existence the sole reality and the essence a mental abstraction. ${ }^{26}$ For Şadrā, existence is everything and knowledge of existence is the requisite for all knowledge,

Ignorance about the question of being, necessarily makes man ignorant of all the principles of knowledge and foundations because it is through being that everything is known, and ... when someone ignores it, he has ignored everything. ${ }^{27}$

Therefore, we cannot speak of anything without considering existence. In the world of being, Mullā Șadrā introduces justice as an existential thing, even identical with the being. He believes that justice dominates the world of creation, and every object is in its own position and the right of every being is fully granted. ${ }^{28}$ Coming into existence means getting your right, "it is by existence that any deserving being reaches to its right." 29

Therefore, justice is identical with existence and existents. Mullā Şadrā explicitly explains this point in Mafätīh al-ghayb. As for the Divine creational order of 'Be' he says that this order is not by force and constraint but, in fact, it is the Divine permission to include the objects into Divine 'justice' which is identical with the 'existence,' because things seek permission from God to come into being, and God, the All-Merciful, allows them by the creational word of 'Be,'

And His statement $B e$ is not by force and constraint, because Allah is indeed free from need of the creatures, nor does He have a need for their existence. Rather, this order is indeed a permission (for them to come into existence), since it is preceded by asking for existence. It is therefore as though the creature has said to his Lord, "Let me enter your

25 For a useful English report of the critics of al-Suhrawardi against the doctrine of the primacy of existence and Șadrā's defends, see: Fazlur Rahman, The Philosophy of Mullā Șadrā (Albany: State University of New York Press, 1975), 31-33.

26 Mullā Șadrā, al-Asfār, I, 38-44.

27 Mullā Șadrā, al-Shawāhid al-rubūbiyyah, 141.

28 Mullā Ṣadrā, "Risālah fī l-wāridāt al-qalbiyyah," 251.

29 Mullā Ṣadrā, Mafātīḥ al-ghayb, 321. 
[realm of] justice which is identical with your [realm of] existence," and Allah replied, "Be," or "Enter My realm, I have allowed you." 30

Mullā Ṣadrā along with other Muslim philosophers, admits "the best ordering" in the creation and it seems that his ontology can better support this notion. According to gradation or modulation of existence (tashkik al-wujūd) - another main existential principle in al-Hikmah al-muta'āliyah - though one single reality, existence comes in grades, similar to the reality of light in which sunlight and candlelight, for example, are of the same reality yet in different grades. Mullā Ṣadrā says, "The instances of existence are [the same in their reality but] different in terms of intensity and weakness, priority and posteriority, as well as nobility and baseness." 31

Therefore, though of the same type, the existents do not enjoy the same grade, but there exists a hierarchy of existence which includes the whole universe. In this hierarchy, the completer and more intense the existent, the higher its position. So that the highest being is the most complete (God) and the last and lowest one enjoys the least portion of perfection and is the nearest to the realm of nothingness (primary matter),

We have already proven that the existence of each thing has a special level of manifestation and a specific degree of actuality and realization, and the ultimate in glory and majesty is self-existent, all-sufficient, necessary, and independent from others, then He qua He, is mere actuality and is sacred from all impurities of potentiality, contingency, imperfection, and deficiencies. Everything other than Him is accompanied by essential contingency and deficiencies in proportion to their diverse degrees and different levels. Therefore, the farther it is from the source of existence and necessity, the more is its contingency and deficiencies until the existence reaches such a level of descent and baseness that its substantial existence becomes its very subsistence in the form that it assumes and its actuality becomes exactly the same as its potentiality [i.e. it has no actuality]. ${ }^{32}$

Is it not possible for things to be in a position other than what they are now? Mullā Șadrā's answer is obviously negative. Based on the

\footnotetext{
30 Mullā Ṣadrā, Mafātīh al-ghayb, 205.

31 Mullā Șadrā, al-Asfār, IX, 186; see also F. Rahman, The Philosophy of Mullā Șadrā, 35.

32 Mullā Ṣadrā, al-Asfār, I, 339; see also, ibid., V, 2; id., Mafātīḥ al-ghayb, 234-235.
} 
gradation of existence, all the beings have the same existential reality and the only difference can be the quantity and the quality of existential perfection they possess, that is, the only difference between existents can be justified and explained merely through possession of different grades and positions as well as different existential characteristics. Thus, the specific position of any existent determines its individuation and cannot be removed or changed. In other words, 1. everything is in its own position in creation (and cannot be other than that), 2. Everything receives its own creational rights or its existential characteristics like knowledge, power, etc. Is it not exactly what justice requires?

Before explaining justice in the human world - including individual justice and social justice - it is necessary to focus on the fact that, in Mullā Șadrā's view, this kind of justice is a reflection of existential justice. Although justice is a normative concept, it is not a mere mental construct; rather, it is derived from reality and the existent world. Șadrā explains the necessity for justice in the human world - both in the human soul (individual justice) and in human society (social justice) based on the existence of justice in the world of creation. He depicts many aspects of the compatibility of individual and social justice with existential justice. In fact, if we ask Șadrā "why should one be just?" he will answer, "because the world of creation is just." Otherwise, the incompatibility between the inner world (microcosm) and the outer world (macrocosm) will make the person as if he is swimming against the flow of water and, as a result, does not achieve what he wants, or as Mullā Ṣadrā says there would be enmity between the one who is far from justice and the just system of existence, and this enmity will lead to his defeat and his failing to achieve what he aspirates,

He who follows the caprice and sensuous appetite, which are contrary to wisdom and justice - while the heavens and earth subsist by wisdom and justice - then the world of existence as it is, is corrupted for him, and woe to him for whom the world [of existence] becomes corrupt and his nature opposes the wisdom of being and the system of existence. The giver of subsidence to the world and the Overhearer of the heavens will take revenge from him because he is the enemy of God and the enemy of the world. So, his state will be as God clarifies by His saying, "Had the truth followed their desires, the heavens and the earth would have surely fallen apart [along] with those who are in them." (Q 23: 71) So, incontrovertibly, he is prevented from what he covets (and) is veiled from what his caprice calls for, as He the Exalted 
said, "And a barrier is set between them and what they desire." (Q 34:

$54)^{33}$

This is not limited to the individual realm, but also includes the social arena, because Șadrā, according to the verse "Indeed Allah does not change a people's lot unless they change what is in their souls," (Q 13: 11) argues that if the divine potentials and blessings (in a society), are not used for the purposes they are created for (i.e. not used according to justice), the blessings will be taken away. ${ }^{34}$ On the other hand, the ultimate happiness of the habitants on earth is to obey God and His laws to be able to realize in their society the justice that is established throughout creation and the justice that the heavens subsist by. ${ }^{35}$

Why should we obey God and His laws? According to Șadrā, the answer to this question is another justification for the rationale behind justice. The answer is that since one of the prominent attributes of God is justice (which is manifested in the creation and was already discussed as the "existential or creational justice"), man must be just too. This is rooted in the principle of "becoming similar to God and taking on lordly traits" that is widely accepted by Muslim philosophers. 36

Also, in Șadrā's view, all levels of justice in all worlds of creation are derived from the justice that exists in the Divine Presence. Here, we are confronted with a hierarchy of justice any lower level of which is the manifestation of one upper level: the just system in a desirable society is the product of following the justice that is established by the prophets and has been delivered by them to the just rulers through their just religious laws; then, the justice of the prophets and saints is the result of the justice that is with the angels; and their justice is derived from the justice existing in Divine world which is, "The spring of all (just) arrangement, the beginning of all goodness and beauty, and the source of all perfection and moderation." ${ }^{37}$ According to the

33 Mullā Ṣadrā, Spiritual Psychology: The Fourth Intellectual Journey in Transcendent Philosophy (Volumes VIII and IX of the Asfär), trans. Latimah-Parvin Peerwani (London: ICAS Press, 2008), 663. (with little alteration)

34 Mullā Șadrā, Tafsìr al-Qur’ān al-karìm, III, 391.

35 Ibid., II, 248.

36 See Mullā Șadrā, al-Asfār, I, 21-22.

37 Mullā Șadrā, Tafsìr al-Qur'ān al-karìm, I, 140-141. 
verse (Q 25: 57), Șadrā considers the purpose of sending the prophets and codes of laws to be the establishment of justice in human society, which causes the members to take on the conduct of the archangels and to accompany the prophets and saints in the Holy Residence. ${ }^{38}$

\section{The Criterion for Justice}

As we already discussed, according to Șadrā, the necessity of being just in the human realm is derived from the existence of justice in the creation and from the fact that true happiness comes true only with knowledge of and compatibility with the world of existence and its laws. As a corollary, to find the criterion of justice, we shall also refer to existential justice. According to the aforementioned definition of justice, justice requires to pay attention and use every faculty of the human soul and also to use every individual or group of the society in their proper place and in proportion to their abilities and potentials; and as it will come later, both in the world of creation (macrocosm) and the world of soul (microcosm), reason and rational beings have the highest degree, and therefore, the individual justice and social justice respectively necessitate the superiority of the reason and the wise over other faculties and members. We will now fully explain this matter in each type of justice.

\section{A. Individual Justice}

This kind of justice is a representation of the creational justice in the human soul. In comparison to social justice, we may call it individual justice' and since it is mainly discussed in ethical parts of Islamic philosophy, we may call it ethical (or moral) justice. Ethical justice means a balanced manipulation of faculties which is achieved only through the superiority and control of the reason over all other faculties,

The practical (virtues for the human soul) are the justice and the dominion (of reason) over the faculties of desire (or appetite), anger (or aversion), and theoretical faculties, especially estimate. ${ }^{39}$

38 Mullā Șadrā, Tafsīr al-Qur'ān al-karìm, I, 278.

39 Mullā Șadrā, al-Mabda' wa-l-ma'ād, ed. Jalāl al-Dīn Āshtiyānī (Tehran: Islamic Institute for Research in Philosophy, 1354 HS), 436. See also: Ibid., 361-362; alAsfār, IX, 90, 126-128; Tafsìr al-Qur’ān al-karìm, VII, 64-65; I, 428; Mafātīḥ alghayb, 687. 
On the other hand, corruption and injustice occur when the soul faculties are not manipulated in the purpose they are created for, and the faculties of desire, aversion, and estimate take the control of the soul and dominate the reason. ${ }^{40}$

According to Șadrā, the soul has both practical faculties (al-quwál'amaliyyah) and theoretical faculties (al-quwá l-nazariyyah). ${ }^{41}$ Faculties of sensation ( $h i s s)$, imagination (khaya $\bar{l}$ ), estimation (wahm), and intellect ( $(a q l)$ or reason are among theoretical faculties ${ }^{42}$ and faculties of desire (al-quwwah al-shahawiyyah) and aversion (alquwwah al-ghadabiyyah) are the two motivating ( $\left.b \bar{a}^{c} i t h a b\right)$ faculties which - under the effect of information they receive from faculties of imagination, estimation, and intellect -intrigue the acting (fäcilab) faculty to move the limbs and organs of the body. Desire seeks benefits and interests and aversion relates to disposing of losses, dominating enemies, and getting rid of dangerous events and things. ${ }^{43}$

The fact is that almost all these faculties - except reason - are common between man and other animals. As a higher state of existence, 'humanity' contains every power and faculty that belongs to plants and animals. Vegetation is the most important differentia the plants have. Animals possess the vegetative faculty with a host of other qualities missing in plants such as mobility and sensation. Finally, man contains all of these qualities and faculties in addition to intellect (reason) in which plants and animals lack. ${ }^{44}$ Until here, little is exclusive to al-Hikmah al-muta'äliyah of Mullā Șadrā, rather, the

40 Mullā Ṣadrā, Tafsīr al-Qur’ān al-karīm, II, 249.

41 Mullā Șadrā, al-Mabda' wa-l-ma`ād, 258.

42 Faculty of reason perceives universals and faculties of sensation and imagination perceive particular cognitive forms (al-șwar al-juz’iyyah). As long as the sensual relation with the external object is still there, the perceived form is sensual, and once there is not such relation, the same form would be imaginative. Estimate faculty perceives particular meanings ( $\left.a l-m a^{\prime} \bar{a} n \bar{\imath} l-j u z^{\prime} i y y a b\right)$. See Mullā Ṣadrā, alShawāhid al-rubūbiyyah, 299; id., Mafātīḥ al-ghayb, 524, TTabāțabā'ī, Bidāyat alḩikmah (Qom: Mu’assasa-yi Intishārāt-i Dār al-'Tlm, 1382 HS), 276.

43 Mullā Ṣadrā, Sharḥ al-Hidāyah al-athīriyyah, ed. Muhammad Mușțafá Fūlādkār (Beirut: Mu’assasat al-Tārīkh al-'Arabī, 1422 H), 239-240; id., Mafātīḥ al-ghayb, 500-501.

44 Ibrahim Kalin, Knowledge in Later Islamic Philosophy: Mullā Șadrā on Existence, Intellect, and Intuition (New York: Oxford University Press, 2010), 112, https://doi.org/10.1093/acprof:oso/9780199735242.001.0001. 
discussion goes on the principles of philosophical anthropology accepted by most of the Muslim philosophers who owed these principles mostly to Aristotle. What is novel lies in how the human soul possesses all these faculties. Again here, Șadrā flashes back to the principle of gradation of existence, that is the principle of identity in difference and difference in identity. As "being" is a simple reality that contains the multiplicity of its own modification, and that is one and all other things that exist are its different grades, degrees, and modalities, and that these multiple grades and modalities do not exist in themselves as separate realities ${ }^{45}$ the human soul is also one simple reality that enjoys its own different grades and modalities called faculties which are not separate entities and existents in themselves. There exists a kind of unification between the soul and its faculties, quoting Șadrā, "The soul is all of the faculties." ${ }^{46}$ This is not to be understood to mean that the soul is the collection or aggregate of the faculties since an aggregate for Șadrā has no existence apart from the particulars which make it up; rather, faculties are the "modes (shu'ün)" or "manifestations (mazāhir)" of the soul ${ }^{47}$ and its "essential stations." 48 This is due to the graded unity of the soul that includes many grades and levels,

We have already informed you that the truth of man is a collective reality (baqiqah jam'iyyah) and it has an inclusive unity (wahdah ta'allufiyyah) like the unity of the world with varying ranks in disembodiment and embodiment, and clarity and opacity. That is why it is called the small world (microcosm) since its wholeness is ordered in line with the levels of the existents of the world (macrocosm), which are, despite their being numerous, categorized in three main classes of intelligibles ('aqliyyāt), imaginals (mithāliyyāt) and sensibles (maḥsūsāt) ...; by the same token, the human soul also includes something like the intellect ( 'aql), something like psyche (nafs) and something like nature ( $t a b$ ) any of which has their own concomitants. The perfection of human soul is to depart from the level of nature to the stage of intellect in order to become one of the dwellers of the realm of Divine Sovereignty. This occurs when its inner reality is enlightened through knowledge and is detached from the

45 See Muhammad Kamal, Mullā Sadra's Transcendent Philosophy (New York: Ashgate, 2006), 73.

46 See, Mullā Ṣadrā, al-Asfār, VIII, 51, 221, 226.

47 F. Rahman, The Philosophy of Mullā Șadrā, 172.

48 Mullā Ṣadrā, "Risālah fī l-ḥashr," 344. 
(material) world through practice. ${ }^{49}$

He explicitly puts the reason in a higher rank in comparison to other faculties ${ }^{50}$ and claims its perfection to be more important,

As the existents are different, happiness attained through comprehending each of them will also be different. Also, just as the existence of rational faculties is nobler and higher (ashraf) than the animal faculties of desire and anger and the faculties of the souls of beasts and other animals, in the same token, the happiness and enjoyment gained through its perfection are nobler and more complete. ${ }^{51}$

That is why he believes that the reason must train these animal faculties and prevent them from (being excessively affected by) imaginations and estimations and make them act in a way that the practical reason requires. ${ }^{52}$

In other words, we are faced with two existential hierarchies - the macrocosmic and microcosmic - in which the rational and intelligible stage is the highest level to gain; it is the real truth of humanity and is his ultimate goal in perfection. For Șadrā, parallel to this existential and creational hierarchy, there exists an ethical hierarchy in which the rational aspect of the human must be the highest faculty that controls and manages all other faculties.

In fact, the creational hierarchy in the macrocosm and microcosm is the ontological ground justifying the ethical hierarchy proposed by Muslim philosophers. Referring back to the beginning of this paper, justice is to put everything - including faculties of the soul - in their proper place. According to Sadrā, every faculty has an innate position (al-mawdi ${ }^{`}$ al-fițî) and ethical justice, therefore, requires to use every faculty in what it is created for and let them be in their innate positions

49 Mullā Ṣadrā, al-Shawāhid al-rubūbiyyah, 428.

50 In establishing the ontological status of intelligible forms (and as a result, the faculty of intellect) as "more" and "higher," Șadrā has also adopted an old Peripatetic principle and identifies the basis of intelligibility as incorporeality and disembodiment (tajarrud) and affirmed it by his existential principles, especially, the gradation of existence; for an elaborate discussion, see Kalin, Knowledge in Later Islamic Philosophy, 107-118.

51 Mullā Șadrā, al-Mabda' wa-l-ma'ād, 363.

52 Mullā Ṣadrā, Mafātīḥ al-ghayb, 687. 
(mawä dicuhā l-fitriyyab) ${ }^{53}$. This entails that one must put the highest faculty -the reason- in its deserving position, higher than other faculties so that it can have control over them. Referring to the parallelism of the macrocosm and microcosm, Sadrā clarifies the issue,

The clarification and revealing of this matter to you requires you to know that God has created you similar to Himself. He has made your body and faculties residing therein - which you manage - a small world [microcosm] comparable to the big world [macrocosm], and there is nothing in the (big) world except there is a sample of it in your small world and your kingdom. But the dominant and influential principles in you are: angelic, savage-like, bestial and satanic characteristics. By means of angelic [characteristics] you practice angelic acts like knowledge, purity, obedience, and closeness to the Almighty, by the aversion faculty, you practice the acts of predators like enmity, hatred, attacking people by beating and revilement, and the love of power and authority, by faculty of desire, you practice the acts of beasts such as gluttony, lewdness and greed, and in terms of satanic power, you practice the actions of demons and work out different aspects of evil by ruse, stratagem, and cheating, and get to the intentions of passion and carnal soul. O' man, thus, it is as though an assembly of an angel, a devil, a dog, and a pig are gathered in you and inside your integument: [the angel is the intellect,] the dog is the anger, the pig is the desire and the estimate is an example of Satan. If you, then, undergo struggling these three ... by means of the light of rational insight and... make all subjugated to the management of the intellect, at that point, the condition will be just and the justice will be manifested in the government of body and all [the four different aspects and faculties] will move on the straight path. ${ }^{54}$

If so, the motivating faculties will be kept far from their extremes and this leads to balanced actions done by the person - another manifestation of justice. If not under the control of reason, the motivating faculty would go to the extremes of either desire or aversion which is obviously in contrast with justice. This is rooted in Aristotle's definition of virtue as a condition intermediate (a "golden mean" as it

\footnotetext{
53 Mullā Șadrā, Tafsīr al-Qur’ān al-karìm, VII, 64-65.

54 Mullā Ṣadrā, Sharḅ Ușūl al-Kāfì, IV, 388.
} 
is popularly known) between two other states, one involving excess, and the other deficiency. ${ }^{55}$

\section{B. Social Justice}

As we saw in the preceding section, individual justice is a reflection of the creational justice in the realm of the individual soul. The same is true about social justice, except for the arena which is the human society. Mullā Șadrā argues that human being is required to establish the Ideal City or Utopia's order following the order that exists in the world of creation and its natural systems, including his or her own physical creation. He likens the Utopia to a healthy and perfect body whose members are ranked according to their innate abilities and serve each other, except for the highest and most honorable organ, which is at the top and is considered as the head and ruler of the body. All other natural systems are the same, and anyone who is more honorable and more perfect is in a higher position. Such order, which must also be observed in the Ideal City, is an image of the order in the universal system of creation that represents it in the minor systems,

For the First Cause's relation to all other existents is the same as the relation of the head of the Utopia to all other members of it (and there also exists a hierarchy). Because the intellects disengaged from the material deficiencies rank below the First, then the animae celestes (heavenly souls) and the skies are ranked after them, and below them are the material natures and their physical bodies ... Likewise, the Utopia should be as such ... And the head of the Utopia ... (should have) completed his soul and has become an actualized intellect. ${ }^{56}$

55 See Richard Kraut, "Aristotle's Ethics," in The Stanford Encyclopedia of Philosophy (Summer 2018 Edition), Edward N. Zalta (ed.), https://plato.stanford.edu/entries /aristotle-ethics/, accessed October 2, 2020.

56 Mullā Șadrā, al-Mabda' wa-l-ma`ād, 490-492. As for the term "actualized intellect," Muslim philosophers consider different levels of perfection for the soul in terms of his noetic potentiality; the last or near the last stage is what they call "intellect in actu (al-'aql bi-l-ficl)" that the soul, whenever needed, presents the intelligible concepts without the need to contemplate; for instance, see Mullā Șadrā, Mafātīh al-ghayb, 20, 136. It is also important to know that Șadrā is highly influenced by alFārābī on the concept of Ideal City; cf. Richard Walzer, Al-Farabi on the Perfect State: Abū Naṣr al-Fārābī's Mabādi' àrā abl al-madina al-fādila (Oxford: Clarendon Press, 1985), 233-243. In his Virtuous City, al-Fārābī was himself influenced by Plato's Republic. Having "fully acknowledged the political aspects 
As in the arena of creation, the order of beings from the noble and perfect to the weak means the realization of justice, likewise, in the ethical domain, the superiority of the noble faculty (intellect) entails the realization of ethical justice. Correspondingly, in the social realm, the most important element of the realization of social justice is the rule of the wise and scholars. According to Mullā Șadrā and other Muslim scholars who divide the internal main faculties of humankind into desire, aversion, and reason, people can also be divided into three groups: people of desire, people of aversion, and people of reason.

As within the realm of the individual, justice is actualized when the reason is given rule over other faculties, also in the social scope, the people of the reason (the wise) must be at the head of the society, "When justice is maintained the desires are subject to reason and if injustice rules, the reasons will follow the lusts." ${ }^{57}$ Sadrā's view of individual justice and the division of people on this basis can clarify that only those who are most in line with the world of creation, both in the realm of theory and action, deserve to rule and lead the society.

The necessity for rulers of a just society to be qualified in terms of moral justice may be justified by this philosophical principle that, "It is

of Plato's thought" (Walzer, "al-Fārābī,", in Encyclopaedia of Islam, Second Edition, 779-780) al-Fārābī had followed his lead in characterizing the chief ruler but had invested him with prophetic qualities in addition to Plato's philosophic traits. (Majid Fakhry, Al-Fārābì, Founder of Islamic Neoplatonism: His Life, Works, and Influence [Oxford: Oneworld Publications, 2002], 104). Apart from any other developments Șadrā might have made to al-Fārābī's ideal city (his novel theory of the soul as a good example), what we will focus here is that Șadrā adopted alFārābī's Islamizing approach toward Plato's legacy and made it more Islamic and even Shī̄ì by investing the ruler with more religious characteristics and by extending the prophetic authority and traits to Imams and also to religious scholars. To find more about the influence of Plato's political theory on al-Fārābī see, Ishraq Ali and Mingli Qin, "On the Relation of City and Soul in Plato and Alfarabi," Journal of Arts and Humanities 8, no. 2 (2019), 27-34, and for an instance of linking between Plato's political legacy and contemporary Iran, see Vanessa Martin, "A Comparison Between Khumainī's Government of the Jurist and the Commentary on Plato's Republic of Ibn Rushd," Journal of Islamic Studies 7, no. 1 (1996), 1631, https://doi.org/10.1093/jis/7.1.16.

57 Mullā Ṣadrā, al-Shawāhid al-rubūbiyyah, 367. 
impossible for the one who lacks a perfection to provide it." ${ }^{58}$ If a person does not enjoy justice in his inner self, how would he be able to establish justice among others in the society? Never! Because every effect is commensurate with its cause, and every work is similar to its performer. A cause and performer that is unbalanced and unjust, cannot produce a moderate, harmonious, and just effect and action. ${ }^{59}$ How can a person who is unable to resolve the conflict between his intellect and his desire resolve the lawsuits of individuals and set up justice among them? ${ }^{60}$ It is narrated from the first Imām of Shī'ah, 'Alī ibn Abī Țālib, saying, "How can one establish justice among others while being an oppressor himself?" ${ }^{11}$ In Mullā Șadrā's description, the conduct of the prophets and the Friends of God (awliy $\bar{a}^{\prime}$ Allāb) is that they start from perfecting themselves and after being perfected and guided, they deal with perfecting and guiding others. ${ }^{62}$ Șadrā refutes any defect and fault from the prophets because of their privilege of infallibility and considers them as the owners of wisdom and the conclusive speech (fașl al-khițāb) ${ }^{63}$ which is a sign of government.

In fact, Mullā Ṣadrā's theory of moral and social justice is influenced by the Shī̄i doctrine of the Imāmate. Morris considers Șadrā's understanding of the imāmate as a crucial point of intersection between his metaphysics and his political and religious philosophy. ${ }^{64}$

In his view, the role of the imām in the society is equal to the role of the intellective faculty in the human soul in being a just ruler who establishes justice,

58 Mullā Ṣadrā, Sharḅ Ușūl al-Kāfì̀, IV, 11; for different expressions of this principle, see his al-Shawāhid al-rubūbiyyah, 168; id. Mafātīh al-ghayb, 325; al-Asfār, II, 307; Tafsìr al-Qur'ān al-karìm, IV, 355.

59 For an elaborate discussion, see Javādī Āmulī, Haqq wa-taklīf dar Islām, 211-212.

60 Javādī Āmulī, Adab-i Qaḍă’ dar Islām (Qom: Esra International Foundation for Revealed Sciences, 1390 HS), 155.

61 'Abd al-Wāḥid ibn Muḥammad al-Āmidī, Ghurar al-ḥikam wa-durar al-kalim: Majmū'ah min kalimāt wa-hikam al-Imām 'Alī ed. Sayyid Mahdī Rajā̄'̄ (Qom: Dār al-Kitāb al-Islāmī, 1410 H), 517.

62 Mullā Șadrā, Sharḥ Ușūl al-Kāfì, I, 197-198.

63 Mullā Ṣadrā, al-Ḥāshiyah 'alá Ilāhiyyāt al-Shifā' (Qom: Intishārāt-i Bīdār, n.d.), 40 .

64 James Winston Morris, The Wisdom of the Throne: An Introduction to the Philosophy of Mulla Sadra (Princeton: Princeton University Press, 1981), 91. 
As God has created a standing leader and a just ruler for perceptive faculties to refer to, which can distinguish between the true and false in the particular perceptions, so a fortiori He has established in the macrocosm an imām who maintains fairness and rules with justice among human beings as the viceregent of God (khiläfat ${ }^{a n}$ min Alläh) whom people refer to for their doubts, ignorance, incidences, and general beliefs. ${ }^{65}$

As a Shī'ī scholar, Șadrā claims that the twelve Shī'ah Imāms and the prophets are the perfect human beings whose creation enjoys a creational justice and balance which is directly done by God Himself,

Be aware that the man guided by the light of God is the most honorable of all creatures... since God had chosen him to be close to Him and has ascribed him to Himself ... God has created him Himself by blowing into it from His (own) soul and kneading the clay for his body with both of His (own) hands ... And he enjoys [...] blessings such as modification ( $\left.\operatorname{ta}^{\prime} d \bar{l}\right)$ ), proportion (taswiyah), completeness of creation, good form and balance (ḅusn al-șürah wa-l-i(tidāl), and good character and justice ... These characteristics and dignities such as being specifically the successor of Almighty God in the microcosm and macrocosm are only for the real ideal man (al-insān al-ma'nawi alhaqiq $\bar{\imath}$ ), not for these similitudes (al-ashbāb) and likenesses (al$a m t h \bar{a} l$ ) of the seeming figures [i.e. the ordinary people who only share the same apparent form of humanity] ... The Lord holds every living being by its forelock and its sustenance lies with Him, and He knows its [enduring] abode and its temporary place of lodging ... so it walks, by nature, in a right manner without misguidance; but as for the human being, due to the existence of the free will that resists against his nature and due to the obtrusion made by the estimate faculty ..., misleading is possible ... and then, he needs someone to guide him ... So, truly the guide is God through the Book and the Messenger - may God bless him and his family - and Imāms who stand in his place. ${ }^{66}$

The infallibles have reached the peak of individual justice which makes them be considered as role models for others in ethical justice; according to Șadrā, the șirāt (path) on the Day of Resurrection, which is drawn upon the Hell and is the bridge for people to reach Heaven and salvation, has two faces: theoretical perfection of the human soul

65 Mullā Șadrā, Sharḅ Ușūl al-Kāfì, II, 404.

66 Mullā Șadrā, Tafsīr al-Qur'ān al-karìm, I, 106-111. 
that entails the perfection of the reason in terms of knowing God and godly intellectual truths, and the practical perfection which entails the attainment of ethical justice. Sirāt is thinner than hair in terms of the former aspect, and is sharper than sword concerning the latter,

The perfection of man in his travel toward God is dependent on the completion of his powers; as for the scientific [aspect], it depends on reaching the certainty in the accurate theories that are more delicate than hair among the divine signs, and as for the practical [aspect], it depends upon the moderate acting of the faculties of desire, aversion and estimate to achieve the habitus of justice, which is sharper than a sword. Therefore, the straight pass (al-șirāt al-mustaqìm) has two faces: one is more delicate than hair and the other sharper than a sword. ${ }^{67}$

On the other hand, according to Shì̄ì hadìths, Sadrā believes that the truth of the straight path (al-șirāt al-mustaqim) is the truth of the Imām,

And it is mentioned in the hadith narrated by Mufaḍal ibn 'Umar from Abū 'Abd Allāh (P.B.BH.), as saying, "The path (al-șirăt) is the way to know God, the Almighty, and there are two paths, one is in this world and the other in the next world; as for the path that is in this world, it is the Imām whose obedience is obligatory. Those who know him in this world and follow his guidance will pass the path that is the bridge over the Hell in the Hereafter." ... And also, al-Ḥalabì narrated from Abū 'Abd Allāh (P.B.BH.) who said, "The straight path is the Commander of the Faithful [i.e. 'Alī ibn Abī Ṭālib]." ${ }^{68}$... and it is [narrated] from them (P.B.U.T.) as saying, "We are the straight path." ${ }^{69}$ And these hadiths narrated from our masters are compatible in [apparent] meaning and inner [meaning] whose clarification needs an extended explanation, ... but in short, we can say: the human soul, from the beginning point of its creation to the end of its earthly life, goes through mental transformations (intiqālāt nafsāniyyah) and substantive changes (harakāt jawhariyyah) in its essential modes of being (nash'ah dhätiyyah). Hence, every soul is a path (șirāt) to the Hereafter in one

67 Mullā Șadrā, al-Shawāhid al-rubūbiyyah, 366; Mafātīḥ al-ghayb, 644-645, 691; alAsfār, IX, 285; see also, Sharḥ Ușūl al-Käfì, I, 423; II, 294, 578; Tafsìr al-Qur’ān alkarim, VI, 284, 286.

68 Mullā Ṣadrā, Sharḥ Ușūl al-Kāfì, IV, 274.

69 Ibid., 152. 
sense, ... some are straight, some are oblique, and some are reversed; and among the straight paths some are reaching, some are stopped or suspended; and among the reaching paths some are fast and some are slow; and the most complete among the straight paths is the soul of the Commander of the Faithful, and next are the souls of his infallible sons; this is based on the (degree of perfection of) practical and theoretical faculties that the above hadith referred to as the two paths in the present and the next world. The first [i.e. perfection of the practical faculties] is to obtain justice and a habitual state of moderation, between excess and deficiency, in the practical reason's employment of the faculties of desire, aversion, and estimate ... This does not happen except through submission to the divine law and obedience of the Imām whose obedience is obligatory. This is what it means that "the path in this world is the Imām." The second [i.e. perfection of the theoretical faculties] is for the soul to cross over the [different] levels of existents and the sensible, psychic, and intelligible stages by means of its theoretical faculty and its practical reason, and to depart from the coverts of veils and coverings into the galaxies of the divine lights. ${ }^{70}$

The Imāms are not only the practical aspect of sirāt but also its scientific face, because, in truth, the path of God in terms of knowledge is faith in Him and in the Last Day, and this cannot be achieved except by them and by means of their knowledge. Therefore, they are also the path of God in that sense. ${ }^{71}$

The philosophical explanation of this fact that the Imām is the truth of sirāt and the embodiment of justice in such a way that justice has become his very existence can be explained well through Sadrā's existential principles: human in Aristotle and his Muslim followers before Șadrā is the lowest species (i.e. it cannot be differentiated into

70 Mullā Șadrā, al-`Arshiyyah, ed. Ghulāmḥusayn Āhanī (Tehran: Mawlá, 1361 HS), 263-265. Khomeini also identifies the true justice with șirạt mustaqim which is primarily the path of the perfect human-Muhammadan path-and secondarily the path of other prophets and saints; Khomeini, Sharb hadìth junūd 'aql wa-jabl (Tehran: The Institute for Compilation and Publication of Imām Khomeini's Works, 1395 HS), 152-153; see also, Khomeini, Tafsìr Süra-yi Hamd (Tehran: The Institute for Compilation and Publication of Imām Khomeini's Works, 1386 HS), 75-78. He also argues socio-political aspects of sirāt mustaqìm and considers it exclusive to the prophets and saints and after them, the 'ulamā'; Khomeini, Șậifa-yi Imām, XIII, 368-370.

71 Mullā Ṣadrā, Sharḥ Uṣūl al-Kāfì, II, 546. 
further species), but according to the transcendent philosophy, the human is an intermediate species (i.e. it can be differentiated into further species ${ }^{72}$ ) under which many real species can come into existence like the four general types discussed previously: angelic human, satanic human, dog-like human and pig-like human. That is because the human soul, at first, in relation to various existential actualities, is like substratum ( $m \bar{a} d d a b)$ which enjoys only the capacity and potential to acquire them, but in its substantial motion and essential transformation, acquires any forms of such existential actualities. If they gradually penetrate the soul, they become habits (malakah) and if this process continues, these perfections and actualities become its constituent differentia in such a way that the soul, through those perfections, takes on a new forma individualis (specific form) and becomes truly equal to them. In other words, along with the intensifying substantial change ${ }^{73}$ of human existence, the psychic faculties, modes, characteristics, and actions that exist within him, such as knowledge and justice, undergo change and intensification. Because in the transcendent theosophy, the soul is united with its faculties and their actions and modes like justice. Therefore, just as the soul itself is constantly intensifying in one aspect or another, so are its repeatedly experienced inner states and actions. For example, a just man at first finds justice within himself as a transitory state $(b \bar{a} l)$, that is, sometimes he enjoys justice, and sometimes he is out of the just path. If he is steadfast on the path of justice, with experience and practice, he will acquire the "habit" (malakah) of justice, and finally, his existence will be equated with justice and, technically speaking, justice will be his constituent differentia. Such a just man can be called "justice" without any exaggeration. ${ }^{74}$

72 See Paul Studtmann, "Aristotle's Categories," The Stanford Encyclopedia of Philosophy (Fall 2018 Edition), ed. Edward N. Zalta, https://plato.stanford.edu/archives/fall2018/entries/aristotle-categories/ 2 accessed May 15, 2020; Farīd Jabr et al., Mawsū'at muștalahāt 'ilm al-manțiq 'inda l-'Arab (Beirut: Maktabat Lubnān Nāshirūn, 1996), 1080.

73 For an overview of the substantial movement in Mullā Ṣadrā, see F. Rahman, The Philosophy of Mullā Șadrā, 82- 94.

74 For an elaborate discussion, see Javādī Āmulī, Șūrat wa-Sìrat-i-Insān dar Qur'àn, ed. Ghulām 'Alī Amīn al-Dīn (Qom: Esra International Foundation for Revealed Sciences, 1381 HS), 159-163, and his, Qur'ān-i Hakìm az Manzar-i Imām Rid̄ā 
As we already saw, Sadrā called the prophets and the imāms, especially Imām 'Alī, "al-șirăt al-mustaqìm" and as we will see, he would call them "mizzān (just scales)." He argues that,

Any word or action leaves a temporal effect on the soul and leads it to a special transitory state. If the words and actions are repeated, their effects will be affirmed and the states will turn into habits since the difference between state and habit lies in intensity and weakness. The intensification of the quality [soul's state] leads to the existence of a form, that is, a substantial cause in the soul ... When the state of the soul is intensified, it becomes a firmed habit, that is, a psychic form which is the cause of its own special effects ... (In the Hereafter,) the firmed psychic habits become substantial forms, even independent efficient essences in the soul $\ldots{ }^{75}$ And the human individuals on the Day of Resurrection are resurrected and gathered with different forms ('ala șuwar mukbtalifah) which are the forms of their repeated actions in this world, therefore, they become multiple different species; some of them are from beasts, some from predators, some are demons and some are angels. ${ }^{76}$

Therefore, the character and deeds of the Imām is the criterion for measuring the deeds and morals of others, because, they are the manifestation of true justice in the world - justice in terms of thought, opinion, attributes, and actions. Here, Sadrā uses the Qur'anic term of $m \bar{z} z \bar{a} n$ (Scale or Balance) which in his view, also bears the meaning of moral justice. ${ }^{77}$ According to Shiite Hadiths, mizann is equal to the prophets and the Imāms,

The balance is a valid criterion by which the size and weight of a thing are known, ... and the scale in the Hereafter is of a different type in which the books and the scrolls [of deeds and beliefs] are put and by which they are measured. Among the traditions narrated from our Imāms (P.B.U.T.) in this regard, is what Muhammad ibn 'Alī ibn Bābawayh has narrated that Hishām ibn Sālim asked about God's

(P.B.U.H.) (Qom: Esra International Foundation for Revealed Sciences, 1389 HS), 34- 35.

75 Mullā Șadrā, Asrār al-āyāt (Manama: Maktabat Fakhr al-Rāzī, 2007), 315-318; see also his al-Asfār, IX, 290-293; id., al-Hāāshiyah 'alá Ilāhiyyāt al-Shifā', 168.

76 Mullā Șadrā, al-Hāshiyah 'alá Ilāhiyyāt al-Shifā', 168; see also, al-Asfār, IX, 290293, and Asrār al-āyāt, 320-322.

77 For a detailed explanation of the meaning of mizann and how it is interpreted as justice and is related to șirāt, see Mullā Șadrā, Tafsīr al-Qur’ān al-karìm, VI, 281, 289. 
saying, "We shall set up just scales on the Day of Resurrection" (Q 21:

47), the Imām answered, "they are prophets and their successors."78

It is clear from the above that the infallibles are the most eligible for leading the society towards social justice. They are the successors of God in the macrocosm and microcosm, therefore, the closer we are to the Imām, the closer we are to justice in all its realms. In the next rank after the infallibles, it is the divine wise and scholars who are their best followers and the nearest to them in terms of theory and action. As a $S h \bar{\imath} \iota \bar{\imath}$ believer, Mullā Șadrā uses different religious texts to argue that the 'ulam $\bar{a}$ ' or top $S h \bar{\imath}(\bar{\imath}$ scholars are ranked below the Prophets and the Friends of God (awliy $\left.\bar{a}^{\prime}\right)$. He ascribes some attributes to the Prophet (P.B.U.H.) the most honorable of which is the knowledge of the divine sciences and the knowledge of the truths of things. He claims that the true scholars, who are the elite among the Prophet's nation, also inherit this characteristic. That is, they take their knowledge from the prophet and they are epistemically ranked below him; he explicitly says,

This noble prophetic rank is one of the levels that the human soul reaches when its two faculties (both theoretical and practical) are completed with knowledge and obedience, and this occurs primarily to the Muhammadan soul (al-nafs al-Muhammadiyyah) - peace and salutations be upon him and his family - and to the elites of his nation and the Friends ( $a w l i y \bar{a}^{\prime}$ ) of God secondarily; [this is] because of His saying, "Say, 'If you love Allah, then follow me; Allah will love you.," (Q 3: 31) and His saying, "Whoever obeys Allah and the Apostle they are with those whom Allah has blessed, including the prophets and the truthful ..." (Q 4: 69) It has been narrated, "The scholars are the inheritors of the prophets." ... and is narrated from the Prophet -peace be upon him and his family -, "God has worshipers who are not prophets [and martyrs] but are envied by the prophets [of the sons of Israel]," and, "The scholars of my nation are like the prophets of the sons of Israel." O' You the scholar, unless your sciences are taken from the prophetic niche, you are not a scholar in truth, but by metaphor. ${ }^{79}$

According to Sunnī and Shī' $\overline{1}$ hadīths, Șadrā ascribes some characteristics to scholars in his commentary on al-Käfí by Muhammad ibn Ya'qūb al-Kulaynī (d. 329/9441), Sharḥ Ușūl al-Käfì: after the

\footnotetext{
78 Mullā Ṣadrā, al-'Arshiyyah, 271-272.

79 Mullā Ṣadrā, Tafsīr al-Qur’ān al-karìm, VII, 152- 155.
} 
prophets, they rank above all other creatures, and in deep understanding of the religion, they are like the prophets; ${ }^{80}$ they are inheritors of the prophets, trustees of Allah on earth, masters and leaders of people, vicegerents of the Prophet ${ }^{81}$ and those whose obedience is obligatory upon the rulers, and not vice versa. ${ }^{82}$

According to the theory of justice, 'ulama's's being the best and highest after the prophets is the ground of their guardianship and governance in society over others. Therefore, from Șadrā's point of view, there is a direct relationship between knowledge and authority. He explicitly refers to it when explaining the meaning of the Verse of Obedience or $u l \bar{u}$ l-amr verse which reads, "O' you who have faith! Obey Allah and obey the Apostle and those vested with authority among you." (Q 5: 59). He considers the criterion of being the "vested with authority" to be knowledge; even Abl al-bayt (P.B.U.T.) are considered as the examples of the verse because of their knowledge being the highest,

And, based on the most valid interpretations, the referent of $u l \bar{u} l$-amr is either the scholars of God and the Last Day in general, or the infallible Imāms (peace be upon them) - as it is supported by our fellow believers - because they are the most knowledgeable of the scholars; both interpretations go back to knowledge and its perfection. ${ }^{83}$

He also considers the reason for the sovereignty of awsiy $\bar{a}^{\text {' (the }}$ successors of the Prophet) to be their possession of knowledge,

As for the successors being masters, [this is] due to the fact that they are the most eminent, the best, and the greatest scholars. (On the other hand,) The scholars are the masters of people, because at the level of humanity and in regard with the reality of the human being -i.e. the reason, discernment, and intellection - they are the greatest and most complete. And the superior among the superiors is prior to being the superior and the greatest (of all). The successors - peace be upon them - then, are prior to be the masters of all creatures, except the prophets - peace be upon them. ${ }^{84}$

\footnotetext{
Sharḥ Ușūl al-Kāfî, II, 100.

81 Ibid., 88-89.

82 Ibid., 91.

83 Ibid., 91.

84 Ibid., 47-48.
} 


\section{The Realization of Justice}

From what has been said in the previous section, it can be deduced that according to Mullā Sadrā, the realization of justice is not possible without divine law, and without following the Prophet and the Imāms. This is true of both moral justice and social justice. Sadrā emphasizes that justice finds meaning through "managing the faculties of aversion and desire under the command of religion and reason," ${ }^{85}$ or he says, "that [i.e. justice] is not achieved except through submission to the religious law ( $\left.\operatorname{sharì}^{c} a h\right)$ and obedience to the imām whose obedience is obligatory." ${ }^{86} \mathrm{He}$ considers the divine law to be a justice-based rule ${ }^{87}$ and he believes that it is only through obedience to God and submission to His religious laws that social justice can be realized and injustice and unfairness be driven away. ${ }^{88}$

Justifying this view, one may argue that justice is the placement of things in their true position. This requires knowledge of the truth of things. Such knowledge is out of human's ability, rather, depends on divine revelation through prophets in the form of divine law $\left(\operatorname{shari~}^{`} a b\right)$. Therefore, the realization of justice requires holding fast to the sharì'ah and its owner which is the Prophet and the Imām. Mullā Sadrā considers every action and thought that occurs within the soul to have a special effect on the soul and believes that recognizing what effect every action and thought has on the soul requires revelatory knowledge brought by the prophets,

To get to know the properties of each of them [actions and thoughts] [and their effect on the human soul] and to have a perfect knowledge of them can appear only from the high horizons (matāli) of the sayings of the people of Sanctity and Purity among the prophets and saints who take their knowledge from the world of revelation and inspiration and deliver it to the nation in order to inform them of it, due to the impotence of their intellects to get to know the effect of any action, word, thought and intent. ${ }^{89}$

\footnotetext{
85 Mullā Ṣadrā, al-Asfār, IX, 90.

86 Mullā Ṣadrā, al-'Arshiyyah, 264.

87 Mullā Ṣadrā, al-Mabda' wa-l-ma'ād, 393.

88 Mullā Șadrā, Tafsìr al-Qur’ān al-karìm, II, 248.

89 Mullā Ṣadrā, Kasr aṣnām al-jābiliyyah, 150.
} 
'Abd al-Razzāq Fayyāọ Lāhìjī, disciple and son-in-law of Mullā Șadrā, brought forth an argument in his Shawāriq al-ilhām (Illuminations of the Inspiration) that complements that of his tutor,

The acquisition of the habit of justice ... depends on the knowledge of the effect and the amount of effect of every action and practice in terms of quantity and quality on the soul, which could not be explained in detail by human beings. Rather, it is based on the divine teaching and definition that is achieved by sending prophets and messengers and making religious laws and general regulations. Therefore, obtaining the habit of justice and acquiring the refinement of character traits rest on the existence of prophets and under their direction and guidance peace be upon them all. ${ }^{90}$

Following Ibn Sīnā, Șadrā also considers the existence of social life to rely on the existence of justice, and the realization of justice to depend on the existence of a divine just ruler (prophet) with a just law $\left(\operatorname{sharī~}^{\top} a b\right) .{ }^{91}$

Mullā Hādī Sabziwārī, an eminent Shīì̄ philosopher, gnostic, and jurist in the Qajar period, who ensured the continuation of Mullā Șadrā's influence until today, argues that justice requires preferring the superior ( $a f d a l)$ over the inferior (mafduil) [for ruling the society], because the management of the territory should be in accordance with shari ${ }^{\prime} a b$ and the law of justice, and this demands great knowledge and justice (in the ruler) which is fully explained in the science of ethics. Therefore, the leader (imām) must be superior to others in terms of knowledge, justice, nobility, courage, and management of the nation. ${ }^{92}$

Based on Shīīi narrations, Șadrā considers the prophets and imāms as God's "authority" or "proof" (bujjat Allāh) focusing primarily on a famous tradition that says, "the earth would not sustain in existence

90 'Abd al-Razzāq ibn 'Alī ibn al-Ḥusayn al-Lāhījīi, ed. Zain al-Abedin Qhorbani (Tehran: Nashr-i Sayeh, 1383 HS), Shawāriq al-ilhām, 686.

91 Mullā Ṣadrā, Sharḅ Ușūl al-Kāfì, II, 392; Abū 'Alī al-Ḥusayn ibn 'Abd Allāh Ibn Sīnā, al-Shifā': al-Ilāhiyyāt, ed. Sa`̄̄d Zāyid (Qom: Maktabat Āyat Allāh Mar'ashī, 1404 H), 441-442; id., al-Najāt min al-gharq fì baḥr al-ḍalālāt, ed. Muḥammad Taqī Dānishpazhūh (Tehran: Tehran University Press, 1379 HS), 709-710.

92 Mullā Hādī-yi Sabziwārī, Asrār al-ḥikam, ed. Abū l-Ḥasan Shacrānī and Ibrāhīm Mīyānjī (Tehran: Islāmiyyah, 1351 HS), I, 439-440; also see id., "Hidāyat al-țāibīn fī ma‘rifat al-anbīyā' wa-l-a’immah al-ma'ṣūmīn," in Rasā’il Hakìm Sabziwārī, ed. Sayyid Jalāl al-Dīn Āshtiyānī (Tehran: Uswah Publication, 1376 HS), 278-279. 
without the proof of Allah for His people (bujjat Allāḅ 'alá khalqib)." In his view, khatm-i nubuwwah or the seal of prophethood (the belief that Muhammad is the last prophet) does not entail the finality of the presence of God's proof on earth, rather, it continues its way in the form of Imāmate, with the difference that the Imām does not bring a new divine book including a new legislative revelation. Here, Șadrā is using a synthetic discourse of his philosophy and his Shī' $\overline{1}$ theology to explain and prove the absolute authority of the imām. ${ }^{94}$ According to the principles of his philosophy and based on his theory of justice, the true rulers must enjoy the highest levels of knowledge and morality (with the determining criterion of moral justice); as for the religious side, Shīi $\overline{1}$ traditions and thought consider the prophets and imāms as the best creatures of all, with the highest level of knowledge and moral traits, so that, using Ṣadrā's wording, they are not just persons, but they are "justice."

A very important point in Șadrā's thought which over the last few decades has been in a better position to devote careful attention is that he extends the divine authority of the Imām to religious scholars, especially at the time of Occultation of the twelfth Imām. Except for his above-mentioned statements about the superiority of the 'ulama' (religious scholars) over other groups of people which put them right after the prophets and imāms in rank, there are two more direct clues. The first is a well-known Shī $\overline{1}^{\mathrm{i}}$ tradition which is frequently referred to by the proponents of the modern discourse of the guardianship of the jurist (walayyat-i faqī ) which means the absolute religio-political authority of top religious scholars or jurists. ${ }^{95}$ This hadith is known as

93 Two chapters of the "Book of the Proof" or "Kitāb al-hujjah" of al-Kulaynī's al$K a \bar{f} \imath \grave{\imath}$ deal with this meaning with different wordings; for Șadrā's commentaries regarding this issue, see Sharḅ Ușūl al-Kāfì, II, 468-508.

94 For an elaborate discussion about Șadrā's and his followers' synthetic discourse regarding the authority of Shī̄ì imām, see Meisami, Knowledge and Power, chapters 4-5.

95 See Khomeini, Governance of the Jurist (Walāyat-i faqīh): Islamic Government, trans. Hamid Algar (Tehran: The Institute for Compilation and Publication of Imām Khomeini's Works, n.d.), 128-134; id., Kitāb al-bay`(Qom: Ismācililiyyān, 1363 HS), II, 638-642; id., al-Ijtihād wa-l-taqlìd (Tehran: Institute for Compilation and Publication of Imām Khomeini's Works, 1426 H), 26-30; Javādī Āmulī, Walāyat-i Faqīh, 182, 191-194. 
maqbūlah (an accepted tradition) ${ }^{96}$ of 'Umar ibn Hanẓalah. The focus of their argument is on this part of hadith that in response to 'Umar's question concerning the judicial authority as to whom the Shī'iss should refer to for judgment, Imām al-Șādiq points to the Shīīischolars who are well acquainted with Imāms' hadìths and says, "I have made them governor over you. If one rejects what they judge according to our judgment, he has (indeed) belittled God's judgment and has rejected us, and one who rejects us, has rejected God, and this is as associating 'others' with God (shirk)." ${ }^{\prime 7}$ Ṣadrā simply quotes the narration without any explanation except for a few literary points, and explicitly says that the hadith is so clear which needs no further explanation or commentary. ${ }^{98}$ It seems that maqbülah of "Umar ibn Hanzalah has been accepted by our philosopher, too.

Although here he did not explicitly take a specific position on the theory of walāyat-i faqīh, in al-Shawāhid al-rubübiyyah, Mullā Șadrā emphasizes the authority of the imām and the 'ulamā', specifically jurists, after the closing of the gate of prophethood. Indeed, ijtiha $\bar{a} d$ (the

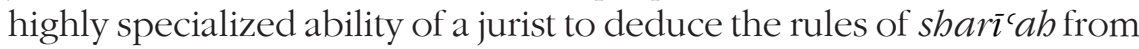
the accepted sources in the Shī' $\overline{1}$ jurisprudence which are: the Qur'ān, the traditions of the Prophet and his infallible household, consensus, and intellect) is the continuation of prophethood and Imāmate and people are required to refer to the top mujtabids during the period of Occultation. Therefore, although after the end of prophecy, the special revelation to the Prophet stops, the nature and function of prophecy (nubuwwah) and messenger-ship (risālah) continue in the Imāms and mujtahids,

[After the Prophet], God preserved the rule ( $\mathrm{bukm}$ ) of the bringers of good tidings (i.e. God's messengers) [(Q 4:165)] and the imāms who are immune to errors (al-a'immah al-ma'șūmin 'an al-khața') salutations be upon them - and the authority of the jurists (almujtahidin). While removing the title [of prophet or messenger] from

96 It is called "maqbülab" (accepted) because although there are some ambiguities about the reliability of its chains of the transmitters, Shī' $\overline{1}$ scholars have accepted this hadith because of its content and some other reasons. See Khomeini, al-Ijtihād wa-l-taqlīd, 26; Javādī Āmulī, Walāyat-i Faqīh, 389-390. On the other hand, some argue that it cannot prove the absolute religio-political authority of the top jurists; see Mohsen Kadivar, Hukūmat-i Welā'̀̄ (Tehran: Nashr-i Nay, 1377 HS), 297- 306. Mullā Șadrā, Sharb Ușūl al-Kāfì, II, 371-372. 
them, He established their authority and commanded anyone who is lacking in the knowledge of the divine judgment (al-buukm al-ilābì) to take their questions to the people of remembrance ( $a b l a l$-dhikr) as God said, "If you do not know, ask the people who know the scriptures (abl al-dhikr)." [(Q 21:7)] So, [the jurists] give their expert opinion (fatwâ) according to their jurisprudence ( $i j t i h \bar{a} d$ ) and they could also disagree just like different religious laws ( $a l$-shara $\left.{ }^{\prime}{ }^{\prime}{ }^{\prime}\right)$ disagree as God said "We have assigned a law and a path to each of you." [(Q 5:48)] Likewise, for every mujtahid, He assigned a law and a path (resulting) from his reasoning ... Thus, the prophecy and the messengership in terms of their nature and their function are not stopped or abrogated, rather, only the revelation exclusive to the messengers and the prophets, which includes the descending of the angels to (convey God's revelation to) their ear and heart, is interrupted, so that neither the mujtabid nor the imām are told to be a prophet or messenger. ${ }^{99}$

Basically, guardianship is a divine quality that the Imāms inherit from the Prophet and the scholars inherit from the Imāms and then from each other, throughout history,

Thus waläyah (guardianship) is a divine attribute ... Some of the

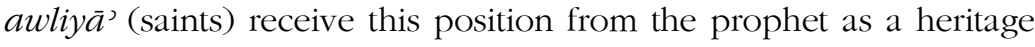
such as the People of the House (Abl al-bayt) - peace be upon them who saw the Prophet in person, then the religious scholars will take it one after another. ${ }^{100}$

This passage is so explicitly attributing the legal-political authority of the prophets and the imāms to jurists which may be a good witness for Mullā Șadrā's contribution to the discursive formation of walāyat- $i$ faqīh. Later, confronting the question as to how the Hidden Imām executes his walāyah and governs the world during his Occultation, based on this Shī ${ }^{c} \overline{1}$ discourse of intermediaries between the imām and the people, Sabziwārī answers,

May people sincerely request the preservation of faith and orthopraxy and knowledge and insight from the "general representatives"

\footnotetext{
99 Mullā Șadrā, al-Shawāhid al-rubūbiyyah, 436. The translation of the quotation is by Meisami, Knowledge and Power, 158-159 with modification and addition.

100 Mullā Șadrā, al-Shawāhid al-rubūbiyyah, 437.
} 
(nuwwāb-i $(\bar{a} m m)$ and the guardians of the community (awliy $\bar{a}^{\prime}-i$ ummah), which is possible. ${ }^{101}$

These explicit statements along with an overall understanding of Șadrā's theory of justice may lead us to accept Mullā Șadrā's legacy of justice as a "discursive springboard" for the establishment of walayati faqi $h .{ }^{102}$ Maybe that would be one of the reasons of the attraction of Mullā Șadrā's philosophy after the Islamic revolution.

In the end, it is worth mentioning the relationship between walayah and knowledge from Mullā Șadrā's point of view, and in this way, trying to more clearly compare his political viewpoint and Khomeini's walāyat-i faqīh. Since according to Șadrā, there is a direct relationship between walayah and knowledge, and knowledge and scholars are of two types, the walayah will also be of two types:

The sharì'ah has both exterior ( $z \bar{a} h i r)$ and interior ( $b \bar{a} t \underline{i n}$ ) aspects, and the ranks of scholars are so different in terms of each: some are superior and some are inferior, as well as knowledgeable and more knowledgeable. Those whose relation to their prophet is more complete and their proximity to his soul is stronger, their knowledge of esoteric and exoteric aspect of his shari ${ }^{c} a h$ will be more. And those who know both the exterior and interior are more deserving to be obeyed, due to their extreme nearness to their prophet; then those who are below them in rank, until the ranking descends to the scholars of the exoteric only, and they also have ranks, since the one who knows both the principles and the ramifications is more entitled to be obeyed than those who are expert only in one ... Thus, each of the esoteric and exoteric aspects has its own experts, all of whom are included under the rule of the Caliph (the Infallible Imām), who is the highest knowledgeable in both aspects. ${ }^{103}$

Such categorization is also found in Fayḍ al-Kāshānī, Șadrā's pupil and son-in-law, who says that the scholars are of three categories:

101 Sabziwārī, Asrār al-ḥikam, I, 452; id., "Hidāyat al-ṭālibīn," 293. Translated in Meisami, Knowledge and Power, 194.

102 Meisami, Knowledge and Power, 185, 186. In contrast, Toussi claims that Ṣadrā's discourse on politics does not provide such a discursive springboard, nor does it promote an idea of quietism or that of a fundamental separation of religion and politics; Seyyed Khalil Toussi, The Political Philosophy of Mullā Șadrā (London: Routledge, forthcoming), introduction.

103 Mullā Ṣadrā, Mafātīḥ al-ghayb, 486. 
those who enjoy only the outward knowledge, those who have only the inward knowledge, and those who are masters of both; only the third (originally) deserve to lead the people. ${ }^{104}$

Observance of the priority in the authority of the Utopia based on having the highest amount of competency, which is a requirement of justice, is what Șadrā has taken from al-Fārābī's political system. According to al-Fārābī, the most deserving person for the governance is the "first head" [comparable to the prophet], followed by the one who is exactly like him and has all his characteristics [comparable to the imām]. However, since al-Fārābī himself was concerned that very few people can enjoy such unachievable levels of qualifications, he suggested that those nearest to them in terms of such qualifications take on this responsibility. For example, they must have the jurisprudence knowledge and be able to deduce unauthorized laws based on the general principles authorized and left by the first head. ${ }^{105}$

Therefore, according to Ṣadrā, when there is no prophet or imām, the best scholars who are closest to them should have authority and should be obeyed. What if even the latter did not exist? We should refer to the esoteric scholars in esoteric matters and to the exoteric experts in exoteric matters, "(Even) al-'ulamā' al-rāsikhūn (those firm in (esoteric) knowledge) must obey (refer to) the jurists and mujtabidin in the exoteric knowledge ... but in the esoteric knowledge, the reverse is true." ${ }^{106}$

Now, it becomes clear that since according to what was previously quoted from Șadrā about the dependence of the realization of justice and governance on the knowledge of $\operatorname{shari}^{\top} a h$, in such a matter, we must refer to the jurists, because the jurisprudence is among the

104 Muḥammad Muḥsin al-Fayḍ al-Kāshānī, al-Kalimāt al-maknūnah min 'ulūm ahl al-ḥikmah wa-l-ma'rifah, ed. 'Azīz Allāh al-'Uțāridī al-Qūjānī (Tehran: Intishārāti Farāhānī, 1360 HS), 240.

105 Abū Nașr Muḥammad ibn Muḥammad al-Fārābī, Kitāb al-millah wa-nuṣūṣ ukhar, ed. Muḥsin Mahdī (Beirut: Dār al-Mashriq, 1991), 73-75; for a more detailed discussion on how Ṣadrā, following al-Fārābī and Ibn Sinā, was made to suggest substitutes for the first head see Mohsen Elahi, "Jāygāh-i Sīyāsah dar Hikmatimuta'āliyah," in Siyāsat-i Muta'āliyah az Manzar-i Hikmat-i Muta'āliyah, ed. Sharif Lakzaei (Qom: Pazhūheshgāh-i 'Ulūm wa-Farhang-i Islāmī, 1390 HS), III, 319-328.

106 Mullā Ṣadrā, Mafātīḥ al-ghayb, 486. 
exoteric aspects of religion. It becomes also clear that how, according to al-Shawāhid al-rubübiyyah, walayyat-i faqīh is the continuation of waläyah of the prophets and imāms. Using Sadrian terminology, waläyah, like existence and knowledge, is a graded reality which includes different degrees. The highest degree is walayah of the prophets and imāms, then the scholars of both the esoteric and exoteric aspects of the religion including the spiritual meaning and the legal sides of it. When we get farther from the infallibles (prophets and imāms), there is no concomitance between the esoteric and exoteric knowledge and a scholar may or may not have both. Therefore, we have to talk about two separate kinds of walayah: exoteric and esoteric. Naturally, walayat-i faqīh is related to the exoteric one. The exoteric waläyah seems to have been neglected by many, even it has been rarely taken into account when we are thinking of the top wali who are the prophets and imāms. Knysh argues that Șadrā's description of the four-step spiritual journey - later adopted by Khomeini - is reminiscent of Ibn 'Arabī's concept of the perfect human (al-insān al-kämil) in its particular emphasis on his functions as a "religious leader of the community of believers" - a function some Western scholars have tended to downplay, instead, focusing on the perfect man's role in the all-important cosmic force tying together the origin and the return. ${ }^{107}$

Of course, for Șadrā, the distinction between exoteric and esoteric realms of walayah and attributing the former to the religious leader does not mean that every expert in the exoteric knowledge like the Islamic jurisprudence deserves to be obeyed, because, in his view, a jurist also is called "al-'älim al-rabbān $\vec{\imath}$ " (the divinely learned) ${ }^{108}$ and therefore, must have special ethical and moral merits, as discussed in his theory of justice. The same is true about Khomeini's theory of walāyat-i faqīh, in which such distinction does not mean that "any regular" jurist can rule the society! But only a "fully qualified" jurist ( mujtahid jāmic al-sharā'ic) that in addition to his knowledge of fiqh, must have other qualifications, most important of which is enjoying

\footnotetext{
107 Alexander Knysh, "Irfan Revisited: Khomeini and the Legacy of Islamic Mystical Philosophy," Middle East Journal 46, no. 4 (1992), 635.

108 Mullā Ṣadrā, Sharḅ Ușūl al-Kāfì, II, 147, 150.
} 
firmly established characteristics of justice and piety among the spiritual conditions. ${ }^{109}$

In line with the distinction between exoteric and esoteric walayyah, some other factors and realms of exoteric knowledge must be met by the ruling jurist, like the political insight and social perspicacity which are mentioned in the constitution of the Islamic republic as part of the requisites needed for wali-yi faqī ${ }^{110}$ These can be compared to some of the qualifications the head of the Sadrian Utopia must enjoy, such as: "He must be sharp and smart enough to understand the events and the intentions of others ... He should be eloquent and articulate and be able to express completely and clearly what is in his mind." 111 Being persuasive can help him to handle the social chaos since, in the past, the speech was the only way to communicate with both the nation and the administrators of the kingdom, even today; public lecture is one of the best ways for politicians to express themselves and handle different social situations. It also can help him to overcome the enemies in the field of psychological warfare, which is one of the requirements of leadership, along with the ability to handle the physical wars. ${ }^{112}$

\section{Conclusion}

From the viewpoint of Mullā Șadrā, justice has two related senses granting the right to the rightful and putting things aright - which can be realized in three realms of creation, the human soul, and human society. Justice in the last two areas is derived from and justified by justice in creation. Creational justice requires the superiority of intellect and intellectual beings to others. The same must take place in the human realm: moral justice entails the superiority and management of the intellective faculty, and social justice requires the leadership of the wise and most knowledgeable.

An accurate overview of Mullā Șadrā's discourse in justice and the related issues brings forth three basic conditions for the ruler of the society whose goal is to establish justice among people:

\footnotetext{
109 Hamid Algar, Constitution of the Islamic Republic of Iran (Berkeley: Mizan Press, 1980), 67.

110 Ibid.

111 Mullā Ṣadrā, al-Shawāhid al-rubūbiyyah, 420-1.

112 Ibid, 420.
} 
1. To enjoy the highest degree of intellectuality, rationality, and knowledge, because justice requires that everything be in its place, and in Șadrā's view, the place of scholars as possessors of intellectuality and knowledge is higher than all.

2. To enjoy the highest level of moral and individual justice, so that he can establish justice among other members of society.

3. To enjoy the highest level of knowledge about religious and Islamic teachings, because without relying on religion and shari'ah, the establishment of justice in the individual and society is not possible.

Based on his Shī̄ì beliefs, Șadrā claims that these conditions are primarily held by the prophets and the infallible Imāms, peace be upon them, and the next rank is occupied by the religious scholars who inherit the intellectuality, knowledge, and justice from the Imāms. As a corollary, in the case of the absence of the Imāms - such as the absence of the Twelfth Imām - it is the divine scholars who deserve to rule because, after the prophets and imāms, the scholars have the above qualifications. The above three characteristics are very similar to the main qualifications needed for the leading jurist (wali-yi faqī h). According to Article 109 of the constitution of the Islamic Republic of Iran, he must: 1 . be a highly qualified jurist (fully acquainted with Islamic teachings), 2. be just and pious, and 3. have political insight and social perspicacity (which is usually accompanied by a taste of rationality). ${ }^{113}$ Further studies may help to shed more light on the correlation between Mullā Șadrā's legacy and the theory of walayyat-i faqinh, especially if they focus on real contemporary instances of this mutual relationship.

\section{DISCLOSURE STATEMENT}

No potential conflict of interest were reported by authors

\section{ACKNOWLEDGMENTS}

We are indebted to Dr. Fardin Jamshidi Mehr who provided us with some beneficial notes on the topic and Dr. Sayeh Meithami whose

113 Hamid Algar, Constitution of the Islamic Republic of Iran (Berkeley: Mizan Press, 1980), 67; see also Javādī Āmulī, Walāyat-i Faqīh, 136-140. 
generous and useful feedback was so supportive. Sincere thanks also go to Mahsa Raeisi Sattari and Shima Pooyanejad for their helpful comments on the English text.

\section{BIBLIOGRAPHY}

Qara'i, 'Ali Quli. trans. The Holy Qur'ān. Mashhad: Behnashr, 2013.

Algar, Hamid. Constitution of the Islamic Republic of Iran. Berkeley: Mizan Press, 1980.

Āmidī, 'Abd al-Wāḥid ibn Muḥammad. Ghurar al-ḥikam wa-durar al-kalim. Edited by Sayyid Mahdī Rajā' '̄. Qom: Dār al-Kitāb al-Islāmī, 1410 H.

Āshtiyānī, Sayyid Jalāl al-Dīn. Sharḥ-i Muqaddame-yi Qayṣarī bar Fușūṣ al-ḅikam. Tehran: Amirkabir Publication, 1370 S.H.

Dughaym, Samīh. Mawsū'at mușțalaḥāt al-Imām Fakhr al-Dīn al-Rāzī. Beirut: Maktabat Lubnān Nāshirūn, 2001.

Elahi, Mohsen. "Jāygāh-i S̄yāàs dar Hiikmat muta āliyah." In Sīyāsat-i Muta'āliyah az manzar-i Hikmat-i muta'äliyah, edited by Sharif Lakzaei, III, 293-332. Qom: Pazhūheshgāh-i 'Ulūm wa-Farhang-i Islāmī, 1390 HS.

Fakhry, Majid. Al-Fārābì, Founder of Islamic Neoplatonism: His Life, Works, and Influence. Oxford: Oneworld Publications, 2002.

Al-Fārābī, Abū Naṣr Muḥammad. Kitāb al-millah wa-nuṣūṣ ukhar. Edited by Muḥsin Mahdī. Beirut: Dār al-Mashriq, 1991.

Al-Fayẓ al-Kāshānī, Mullā Muḥsin. al-Kalimāt al-maknūnah min 'ulūm ahl al-ḥikmah wa-l-ma'rifah. Edited by Azizollah Atarodi. Tehran: Farahānī, 1360 HS.

Darabī, Tālebi. “"Insān wa-Jahān dar Niẓām-i Fikrī-yi Shahīd Beheshtī Beheshtī (Man and the World in the Intellectual System of Shahid Beheshti)." Pigāh-i Hawzah, no.185 (1385 S.H.). https://hawzah.net/fa/Magazine/View/3814/5001/43647. Accessed October 11, 2020.

Fazlur Rahman. The Philosophy of Mulla Sadrā. Albany, New York: State University Press of New York, 1976.

"Gozāresh-i neshasthā-yi wujūh-i sīyāsī-yi Ḥikmat-i mutacālīyah.” Pigāh-i Hawzah 217: 27 (1386 Hs.). https://hawzah.net/fa/Magazine/View/3814/4876/40581. Accessed November 15, 2020.

Ibn Sīnā, Abū 'Alī al-Husayn ibn 'Abd Allāh ibn 'Alī. Al-Najāt min al-gharaq fì baḥr al-ḍalālāt. Edited by Muhammad Taqī Dānishpazhūh. Tehran: Tehran University Press, 1379 S.H.

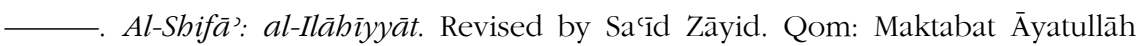
Mar'ashī, $1404 \mathrm{H}$.

Ishraq Ali and Mingli Qin. "On the Relation of City and Soul in Plato and Alfarabi," Journal of Arts and Humanities 8: 2 (2019), 27-34, http://dx.doi.org/10.18533 /journal.v8i2.1568. 
Jabr, Farīd, Samīh Dughaym, Rafīq al- 'Ajam, and Jīrār Jahāmī. Mawsū'at muștalahāt 'ilm al-mantiq 'inda l-'Arab. Beirut: Maktabat Lubnān Nāshirūn, 1996.

Javādī Āmulī, 'Abd Allāh. Adab-i Qaḍă' dar Islām. Qom: Esra International Foundation for Revealed Sciences, 1390 S.H.

- Haqq wa-Taklīf dar Islām. Edited by Mușțafá Khalīīi Qom: Esra International Foundation for Revealed Sciences, 1388 S.H.

. "Hikmat-i Ṣadrā̄̄ì wa-Siyāsat-i Muta‘āliyah dar neshastī ba Āyat Allāh Javādī Āmulī" (Sadrian Philosophy and Transcendent Politics Discussed in a Session with the presence of Ayatollah Javādī Āmulī). Pigāh-i Hawzah 247, no. 19 (1387 HS.). http://ensani.ir/fa/article/64172, Accessed May 1, 2020.

. Qurān-i Hakìm az Manzar-i Imām Riḍā (P.B.U.H.). Qom: Esra International Foundation for Revealed Sciences, 1389 S.H.

. "Siyāsat-i Muta‘āliyah az Manẓar-i Hikmat-i Muta‘āliyah (Transcendent Politics from the Viewpoint of Transcendent Philosophy)." Isrä' Hikmat 7, no. 3 (1390 HS.), 7-18. http://ensani.ir/fa/article/336064SP. Accessed May 10, 2020

—. Sūrat wa-Sīrat-i Insān dar Qur'àn. Edited by Gholam Ali Amīn al-Dīn. Qom: Esra International Foundation for Revealed Sciences, 1381 HS.

- Wilāyat-i Faqīh: Wilāyat-i Faqāhah wa-'Adālah (Governance of the Jurist: Governance of Jurisprudence and Justice). Edited by Muhammad Mehrabī. Qom: Esra International Foundation for Revealed Sciences, 1389 S.H.

Kadivar, Mohsen. Hukūmat-i Welā'ì. Tehran: Nashr-i Nay, 1377 HS.

Kalin, Ibrahim. Knowledge in Later Islamic Philosophy: Mullā Șadrā on Existence, Intellect, and Intuition. New York: Oxford University Press, 2010. https://doi.org/10.1093/acprof:oso/9780199735242.001.0001.

Kamal, Muhammad. Mulla Sadra's Transcendent Philosophy. New York: Ashgate, 2006.

Khomeini, Rūhullāh. Governance of the Jurist (Wilāyat-i Faqīh): Islamic Government. Translated by Hamid Algar. Tehran: The Institute for Compilation and Publication of Imām Khomeini's Works, n.d.

. al-Ijtihād wa-l-taqlìd. Tehran: Institute for Compilation and Publication of Imām Khomeini's Works, $1426 \mathrm{H}$.

Kitāb al-bay‘ 5 vols. Qom: Ismācīliyyān, 1363 HS.

The Lamp of Guidance into Vicegerency and Sanctity (trans. of (Mișbāh albidāyah ilá l-khilāfah wa-l-wilāyah). Translated by Salam Judy. Tehran: Institute for Compilation and Publication of Imām Khomeini's Works, 2010.

. Saḅ̂ifa-yi Imām: An Anthology of Imām Khomeini's Speeches, Messages, Interviews, Decrees, Religious Permissions, and Letters. vol. 21, trans. Mansoor Limba. eds. Husayn Karamyar, Jafar Razi Khan; vol. 13, trans. Hassan Najafi, Dawood Sodagar. ed. Abdol-Husayn Shirazi. Tehran: Institute for Compilation and Publication of Imām Khomeni's Works, 2008. 
Sharb Hadith junūd 'aql wa-jabl. Tehran: The Institute for Compilation and Publication of Imām Khomeini's Works, 1395 HS.

_. Tafsìr-i Süra-yi Hamd. Tehran: The Institute for Compilation and Publication of Imām Khomeni's Works, 1386 HS.

Knysh, Alexander. "Irfan Revisited: Khomeini and the Legacy of Islamic Mystical Philosophy." Middle East Journal 46, no. 4 (1992), 631-653.

Kraut, Richard. "Aristotle's Ethics." In The Stanford Encyclopedia of Philosophy. Summer 2018 Edition. Edited by Edward N. Zalta https://plato.stanford.edu /entries/aristotle-ethics/. Accessed October 2, 2020.

Lāhìjī, 'Abd al-Razzāq ibn 'Alī ibn al-Husayn. Shawāriq al-ilhām. Introduced by Zain al-Abedin Qhorbani. Tehran: Nashr-i Sayeh, 1383 HS.

Martin, Vanessa. "A Comparison between Khumainī's Government of the Jurist and the Commentary on Plato's Republic of Ibn Rushd." Journal of Islamic Studies 7, no. 1 (1996), 16-31. https://doi.org/10.1093/jis/7.1.16.

Meisami, Sayeh. Knowledge and Power in the Philosophies of Hamìd al-Dīn Kirmāni and Mullā Șadrā Shīrāzì. New York: Palgrave Macmillan, 2018. https://doi.org/10.1007/978-3-319-71192-8.

Motahhari, Morteza. Collection of Works (in Persian). Tehran: Sadra, 1373 S.H.

Mulla Ṣadrā, Șadr al-Dīn Muḥammad al-Shīrāzī. al-`Arshiyyah. Edited by Ghulāmḥusain Āhanī. Tehran: Mawlā, 1361 HS.

. Asrār al-āyāt. Manama: Maktabat Fakhr al-Rāzī, 2007.

. "Ajwibat al-masā’il al-Kāshāniyyah." In Majmū'-i Rasā'il-i Falsafì-yi Ṣadr almuta'allihīn, edited by Hamed Nājī Isfahānī. Tehran: Intishārāt-i Hikmah, 1375 HS.

al-Hāāhīyah 'alá Ilāhiyyāt al-Shifāa'. Qom: Intishārāt-i Bīdār, n.d.

. "Iksīr al-'arifīn." In Majmū'at al-rasā’il al-tis'ah. Tehran: n.p., $1302 \mathrm{H}$.

I Iqāz al-nā'iminn. Edited by Mohsin Mu’ayyid. Tehran: Islamic Institute for Research in Philosophy, n.p.

Kasr aṣnām al-jābiliyyah. Edited by Jahangiri. Tehran: Sadra Islamic Philosophy Research Institute, 1381 HS.

—. Al-Hikmah al-muta'āliyah fì l-asfār al-'aqliyyah al-arba'ah (Al-Asfār). 9 vols. Beirut: Dār Ihyyā' al-Turāth, 1981.

al-Mabda’ wa-l-ma`ād. Edited by Jalāl al-Dīn Āshtiyānī. Tehran: Islamic Institute for Research in Philosophy, 1354 HS.

—. Mafātīh al-ghayb. Edited by Muḥammad Khājawī. Tehran: Mu’assasa-yi Taḥqīāt-i Farhangī, 1363 HS.

—. Risāla-yi Se aṣl. Edited by Seyyed Hossein Nasr. 3 vols. Tehran: Tehran University, 1340 HS.

__. "Risālah fī l-ḥashr." In Majmū'at al-Rasā’il al-tis'ah. Tehran: n.p., 1302 H.

. "Risālah fī l-wāridāt al-qalbiyyah." In Majmū'at al-Rasā'il al-tis'ah. Tehran: n.p., $1302 \mathrm{H}$. 
. "Risālat shawāhid al-rubūbiyyah." In Majmū'a-yi Rasā'il-i Falsafì-yi Șadr alMuta'allihīn, edited by Ḥamed Nājī Isfahānī. Tehran: Intishārāt-i Ḥikmah, 1375 HS.

Sharh al-Hidāyah al-athīriyyah. Edited by Muḥammad Mușțafá Fūlādkār. Beirut: Mu’assasat al-Tārīkh al-'Arabī, $1422 \mathrm{H}$.

Sharḅ Ușūl al-Kāfî̀. Edited by Muḥammad Khājawī. 5 vols. Tehran: Mu’assasayi Muțālacāt wa-Taḥqīāt-i Farhangī, 1383 HS.

. al-Shawāhid al-rubūbiyyah fì l-manāhij al-sulūkiyyah. Edited by Jalāl al-Dīn Āshtiyānī. $5^{\text {th }}$ ed. Qom: Bustān-i Kitāb, 1388 HS.

- Spiritual Psychology: the fourth intellectual journey in transcendent philosophy (volumes VIII and IX of the Asfär). Translated by Latimah-Parvin Peerwani. ICAS Press, 2008.

. Tafsīr al-Qur'ān al-karìm. Edited by Muḥammad Khājawī. 7 vols. Qom: Intishārāt-i Bīdār, 1366 HS.

Nasr, Seyyed Hossein. Introduction to The Sacred Foundations of Justice in Islam: The Teachings of 'Ali ibn Abi Tâalib. Edited by M. Ali Lakhani. Canada: World Wisdom, Inc. and Sacred Web Publishing, 2006.

Rāst-qāmatān-i Jāwdāne-yi Târīkh-i Islām. Tehran: collected and published by Bunyād-i Shahīd, 1361 HS.

Rizvi, Sajjad. "Only the Imām Knows Best: The Maktab-i Tafkìk's Attack on the Legitimacy of Philosophy in Iran.” The Journal of Royal Asiatic Society 22, no. 3-4 (2012): 487-503. https://doi.org/10.1017/S1356186312000417.

Rūmī, Jalāl al-Dīn Muhammad. Mathnawī-yi Ma`nawī. Edited by Tawfīq Subhānī. Tehran: Organization of Publishing of Ministry of Culture, 1373 S.H.

Sabzawārī, Mullā Hādī. Asrār al-ḥikam. 2 vols. ed. and intro. Mirza Abū 1-Ḥasan Sha’fsdrānī. Tehran: Islāmiyyah, 1351 HS.

. "Hidāyat al-țālibīn fī ma ‘rifat al-anbīyā’ wa-l-a’immah al-ma'sūmīn," in Rasā'il-

i Hakìm Sabziwārī, edited by Sayyid Jalāl al-Dīn Āshtiyānī. Tehran: Uswah Publication, 1376 HS.

—. Sharh al-Manzūumah. 5 vols. Revised by Hasan Hasanzādah Āmulī. Intro. Mas`ūd Țālibī. Tehran: Nashr-i Nāb, 1369 HS.

Suhrawardī, Shihāb al-Dīn Yahyá ibn Ḥabash, Majmū'at muṣannafāt Shaykh Ishrāq. 4 vols. Revised and introduced by Henry Corbin, Seyed Husain Nașr and Hasanquli Habibi. Tehran: Mu’assasa-yi Muțāla‘āt-i Farhangī, 1375 HS.

Studtmann, Paul. "Aristotle's Categories." The Stanford Encyclopedia of Philosophy. Fall 2018 Edition. Edited by Edward N. Zalta. https://plato.stanford.edu /archives/fall2018/entries/aristotle-categories/. Aaccessed May 15, 2020.

Ṭabāṭabā'̄̄, Seyyed Muḥammad Husain. Bidāyat al-ḥikmah. Qom: Mu’assasa-yi Intishārāt-i Dār al-'Tlm, 1382 HS.

. Nihāyat al-ḥikmah. 4 vols. Edited and revised by Ghulāmriḍā Fayyāọī. Qom: Markaz Intishārāt-i Mu’assasa-yi Imām Khomeinī, 1385 HS. 
Tawassulī, Husain. Mabānī-yi Nazarầ-yi 'Adālat-i Ijtimā̄ì̃. 2 vols. Tehran: Bunyād-i Mustaḍ'afān-i Inqilāb-i Islāmī, 1375 HS.

Toussi, Seyyed Khalil. The Political Philosophy of Mullā Sadrā. London, UK: Routledge, forthcoming.

al-Ṭūsī, Naṣīr al-Dīn Muḥammad ibn Hasan al-Jahrūdī. Sharḅ al-Ishārāt wa-l-tanbīhāt. 3 vols. Qom: Nashr al-balāghah, 1383 HS.

Walzer, Richard. "Al-Fārābī." In Encyclopedia of Islam, edited by Lewis B, Pellat C, Schacht J., new ed., vol 2, 778-781. Leiden: Brill, 1991.

Al-Farabi on the Perfect State: Abū Nasr al-Fārābì Mabādi' ārā' abl almadinah al-fädilah. The University of Michigan, Clarendon Press, 1985. https://books.google.nl/books?id=EdzWAAAAMAAJ. Accessed May 12, 2020.

Winston Morris, James. The wisdom of the throne: An introduction to the philosophy of Mulla Sadra. Princeton: Princeton University Press, 1981. 